\title{
Excesso? $\bigcirc$ debate sobre o nível das reservas internacionais no Brasil
}

\author{
Cinthia Rodrigues de Oliveira* \\ Victor Leonardo de Araújo ${ }^{\dagger}$
}

\begin{abstract}
Resumo
Desde o final dos anos 1990, os países periféricos passaram a acumular reservas internacionais em resposta às sucessivas crises cambiais deste período. Desde então, manter estoques de reservas tornou-se uma estratégia de gestão da política cambial destas economias, sobretudo, a partir da crise financeira global de 2008, quando ocorreu um aumento de forma acelerada dos ativos externos nos países periféricos possibilitado pela melhora dos termos de trocas e das baixas taxas de juros internacionais. No Brasil, as reservas internacionais passaram de US\$36,3 bilhões em 1999, para US\$206,8 bilhões em 2008 e US\$ 345,7 bilhões em 2020. Contudo, o acúmulo de reservas internacionais tem como contrapartida a geração de custos associados à sua manutenção, ensejando o debate a respeito de um nível ótimo de reservas para o Brasil. Mais recentemente, a deterioração dos indicadores fiscais no Brasil motivou um debate sobre usos alternativos para o excesso de reservas, tendo se destacado as propostas de utilizá-lo no abatimento da dívida pública ou para o financiamento do investimento público. Este artigo pretende contribuir para este debate, defendendo que o nível integral das reservas internacionais seja preservado.
\end{abstract}

Palavras-chave: Reservas Internacionais; Dívida Pública; Investimento Público; Brasil. Código JEL: E62; F41; H63.

\section{Abstract}

Since the late 1990s, peripheral countries have accumulated international reserves in response to the successive exchange rate crises of this period. Since then, keeping stocks of reserves has become a strategy for managing the foreign exchange policy of these economies, especially since the global financial crisis of 2008, when there was an accelerated increase in foreign assets in peripheral countries, made possible by the improvement in the terms of exchanges and low international interest rates. In Brazil, international reserves increased from US \$ 36,3 billion in 1999, to US\$206,8 billion in 2008 and US\$ 345,7 billion in 2020. However, the accumulation of international reserves has the counterpart of generating costs associated with its maintenance, giving rise to the debate about an optimal level of reserves for Brazil. More recently, the deterioration of fiscal indicators in Brazil prompted a debate about alternative uses for excess reserves, with emphasis on proposals to use it to reduce the public debt or to finance public investment. This article aims to contribute to this debate, arguing that the full level of international reserves should be preserved.

Key Words: Foreign Exchange Reserves; Public Debt; Public Investment; Brazil.

JEL Classification: E62; F41; H63.

\footnotetext{
Doutoranda do Programa de Pós-Graduação em Economia (PPGE) da Universidade Federal Fluminense (UFF) e coordenadora discente do Núcleo de Estudos em Economia e Sociedade Brasileira (NEB/UFF). E-mail: cin.roliveira@gmail.com.

† Prof. Dr. da Faculdade de Economia da Universidade Federal Fluminense (UFF) e coordenador do Núcleo de Estudos em Economia e Sociedade Brasileira (NEB/UFF). E-mail: victor_araujo@terra.com.br.
} 


\section{Introdução}

Na década de 1980, entrou em curso um novo conjunto de relações internacionais que passou a modelar a dimensão econômica, política e social dos países. Este movimento - que se convencionou a chamar de globalização -, consistiu na mundialização do capital e dos mecanismos que comandam seu desempenho e sua regulação (Chesnais, 1996). Esta tendência resultou de dois processos que ocorrem simultaneamente e de forma global, quais sejam: i) o início da fase mais longa da acumulação de capital; e ii) a progressiva liberalização financeira, desregulamentação e privatização. Foi neste contexto que as economias periféricas foram reintegradas aos mercados financeiros internacionais, tendo como marco - na América Latina - a conclusão da renegociação das dívidas externas.

No Brasil, a consolidação da liberalização financeira deu-se a partir de 1994 e criou as condições para a estratégia de estabilização de preços por meio da adoção de uma âncora cambial. Para a implementação desta estratégia era preciso ter condições adequadas para o financiamento no balanço de pagamentos, como manter elevadas reservas internacionais a fim de sustentar o valor externo da moeda e o equilíbrio das contas públicas. A oferta de ativos com elevados ganhos de capital associados às altas taxas de juros internas e aos prêmios de riscos possibilitou a entrada de vultosos fluxos de capitais no Brasil e parte deles reverteram-se em reservas internacionais. Tendo em vista a absorção intensa de capitais de natureza especulativa, os recursos externos ingressantes aliviaram apenas temporariamente a restrição externa do Brasil e dos países periféricos em geral (Belluzzo \& Almeida, 2002).

Nos anos de 1990, as economias periféricas foram palco de crises financeiras, com impactos particularmente sentidos na América Latina, como a crise do México (1994), dos Tigres Asiáticos (1997) e da Rússia (1998). As crises externas - que outrora eram causadas por dificuldades em rolar a dívida externa - agora eram originadas pelo ambiente de fragilidade macroeconômica e financeira doméstica (Prates, 2002). A partir 
da experiência das crises, o acúmulo de reservas passou a constituir estratégia de gestão da política cambial de muitas economias periféricas. No Brasil, esta estratégia foi favorecida pelo cenário internacional em vigor durante a segunda metade da década de 2000, marcada pelo forte crescimento dos preços das commodities agrominerais e pelas baixas taxas de juros internacionais, que propiciaram ao Brasil acumular superávits na balança comercial. Com efeito, o estoque de reservas internacionais passou de US $\$ 53,8$ bilhões em 2005 para US $\$ 378,6$ bilhões em 2013 - conforme os dados do Banco Central do Brasil (BCB).

O estoque de reservas internacionais é recorrentemente apontado pela literatura econômica como um dos elementos a mitigar a vulnerabilidade externa, ao menos em caráter conjuntural (Carcanholo, 2010; Gentil \& Araújo, 2012). Deve-se considerar também que a literatura econômica demonstra que elevados estoques de reservas internacionais ampliam a autonomia da política macroeconômica, em especial nos países que não emitem moedas aceitas internacionalmente e que estão sujeitas a uma hierarquia monetária, cujo dólar é a divisa-chave do Sistema Monetário Internacional (De Conti, Prates \& Plihon, 2014). Por outro lado, a preservação dos estoques de reserva após a crise de 2008-9 - que foi por muitos considerada a pior crise financeira desde os anos de 1930 -, engendrou um debate a respeito do nível ótimo de reservas. De um lado, as reservas têm como contrapartida um custo fiscal (custo de carregamento); do outro, o enfrentamento da crise financeira de 2008-9 sugeriu que o Brasil possuía um estoque de reservas muito superior ao que em tese seria necessário, já que a perda de reservas entre setembro de 2008 e fevereiro de 2009 foi de apenas US\$ 19 bilhões, 9,5\% do total (BCB). Com efeito, o debate a respeito de um nível ótimo de reservas ganhou notoriedade no Brasil nos últimos anos. Mais recentemente, a deterioração dos indicadores fiscais e a aprovação da Emenda Constitucional $n^{\circ} 95^{1}$ ensejaram um debate

\footnotetext{
${ }^{1}$ A EC/95 foi implementada em 2016 e limita o crescimento das despesas primárias ao longo de vinte anos. Em termos práticos, o limite de despesa primária deve corresponder ao valor referente ao ano
} 
a respeito do que fazer com o excesso de reservas internacionais. Assumindo a existência de um excesso de reservas, calculado a partir de algum parâmetro de um suposto nível ótimo, alguns economistas da tradição ortodoxa, como Bacha (2016), Goldfajn (2017) e Pelegrini (2017) recomendaram a venda das reservas em excesso para abater a dívida pública no conceito de dívida bruta. Por outro lado, economistas como Carneiro e Mello (2017) e Casal Junior (2017) sugeriram utilizar o excesso de reservas para financiar o investimento público.

Este artigo pretende contribuir para o debate a respeito da conveniência ou não de utilizar o suposto excesso de reservas internacionais para finalidades estranhas à mitigação das crises externas, como o abatimento da dívida pública ou o financiamento do investimento público. $\bigcirc$ ponto de partida é que a ideia de que existe um excesso de reservas se ampara em argumentos de natureza fiscal, devido principalmente ao custo de carregamento das reservas. A partir daí, o artigo sugere que algumas mediações precisam ser feitas ao argumento de natureza fiscal, especialmente que outros critérios devem ser incorporados ao custo de carregamento. Quando esses outros critérios são incorporados, mesmo no âmbito puramente fiscal é possível perceber que as reservas não proporcionam somente custos, mas também benefícios. Metodologicamente, este artigo não pretende construir uma relação custo/benefício, mas sugerir que o custo de carregamento não deve ser o principal critério a nortear propostas que recomenda ao Banco Central livrar-se do suposto excesso de reservas. A incorporação desses outros critérios sugerirá - e esta é a principal contribuição do artigo - que o estoque de reservas seja preservado.

Para atingir o objetivo proposto, o trabalho está organizado em quatro seções, além desta introdução. A segunda seção apresenta uma resenha da literatura sobre o que constituiriam níveis ótimos de reservas internacionais, a partir dos quais seria possível

imediatamente anterior, corrigido pela inflação em cada ano, e com base nessa regra a despesa primária do governo central deverá ser reajustada até 2036, com a possibilidade de revisão em 2026 (Brasil, 2016). 
estimar diferentes níveis para o excesso de reservas para o Brasil. Na sequência, a seção três apresenta uma breve resenha do debate a respeito do que fazer com aquele excesso de reservas no Brasil. A seção quatro apresenta estimativas do impacto fiscal das reservas em excesso, mas incorpora outros elementos que permitem lançar dúvidas a respeito do custo de carregamento como único critério norteador da recomendação de se desfazer daquele excesso. Segundo esses novos elementos, sequer seria possível considerar a existência de reservas em excesso. As considerações finais são apresentadas na quinta seção.

\section{O nível de reservas internacionais para o Brasil}

O crescimento das reservas a partir da década de 2000 se revelou um fenômeno impressionante em nível mundial. Dez anos após a crise asiática, as reservas globais passaram de US\$1,6 trilhões em 1997 para US \$ 6,7 trilhões em 2007, de acordo com os dados oficiais do Fundo Monetário Internacional (Currency Composition of Official Foreign Exchange Reserves [COFER], 2020). Em março de 2020, as reservas internacionais alcançaram um patamar de US\$11,73 trilhões, estando US \$ 3,4 trilhões em poder apenas da China.

O estudo sobre o volume ótimo de reservas internacionais iniciou-se nos anos de 1960 com Heller (1966), a partir da comparação entre os benefícios e custos do estoque de reservas acumulado. Contudo, o objetivo central do modelo era a relativa suficiência de reservas - e não o excesso -, pois até o início da década de 1970 os desequilíbrios mais preocupantes nas contas externas eram aqueles provenientes da balança comercial. Portanto, os ajustes das contas externas eram realizados através de variações nas reservas cambiais, de modo a garantir por três, seis ou doze meses as importações do país conforme recomendado pela métrica tradicional obtida pela relação entre reservas e o número de meses de importação. Com base nesta métrica, Rodrik (2006) observou que mesmo as economias menos desenvolvidas já apresentavam saldos de reservas 
superiores a oito meses de importação. A evolução das reservas internacionais nos países emergentes atingiu o indicador superior a três meses de importação desde 2000 e situouse acima de seis meses de importação a partir de 2009.

No caso do Brasil, Pellegrini (2017) também ressaltou que a métrica que considera as reservas internacionais em relação às importações não é adequada, uma vez que este índice foi atingindo prontamente desde o início da década passada. As reservas no Brasil alcançaram treze meses de importação já em 2007, equivalendo ao patamar de vinte meses em 2017 e atualmente encontra-se em dezessete meses de importação. Calculado com base em dados do BCB, ao considerar a posição das reservas de junho de 2020 em relação a doze meses de importação, o saldo de ativos externos excedentes seria de US\$ 177,3 bilhões.

\section{Gráfico 1 - Evolução das reservas internacionais para o Brasil}

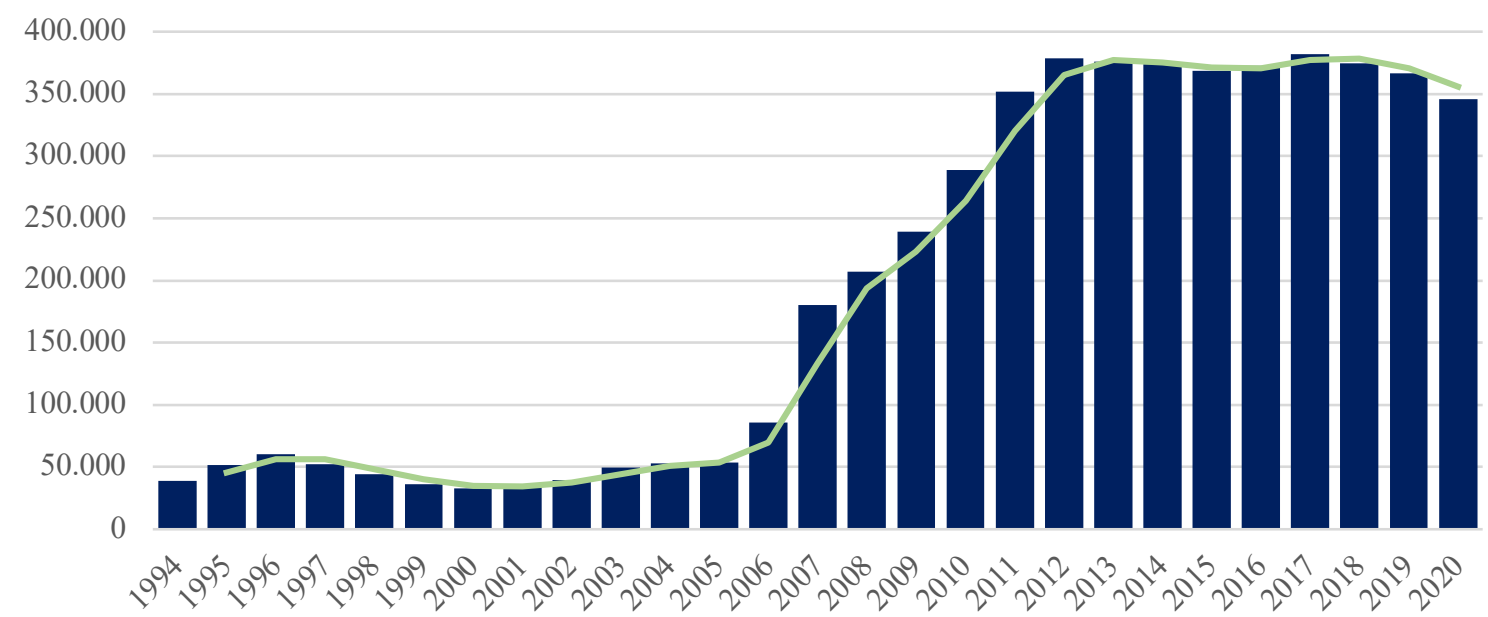

Fonte: Banco Central do Brasil. Elaboração própria.

Nota: Reservas internacionais no conceito liquidez.

A métrica obtida pela relação entre reservas e o número de meses de importação perdeu relevância com o fim do Sistema de Bretton Woods na década de 1970, quando muitos países adotaram a flexibilização dos seus regimes cambiais e a vulnerabilidade externa passou a ser determinada não apenas por choques de comércio (Carneiro, 2012). A experiência das crises externas mostrou que as pressões do balanço de pagamento 
podem surgir de uma série de fontes, tanto na conta corrente como na conta financeira, e os ajustes ocorreriam por meio das variações na taxa de câmbio real. Posto isso, a partir de 1990 observou-se um acúmulo mais expressivo de moedas conversíveis especialmente nos países emergentes onde ocorreram as crises cambiais.

A literatura econômica passou a atribuir às reservas internacionais importante papel na prevenção de crises cambiais e na mitigação dos custos de uma parada súbita dos fluxos de capitais (Rodrik, 2006; Ghosh, Ostry \& Qureshi, 2014). O modelo de Jeanne e Rancière (2006 e 2011) foi um dos primeiros modelos contemporâneos a estimar os custos e benefícios das reservas com base nesse enfoque literário, incorporando na estimação as perdas de produto e contrações de investimento induzidas por crises financeiras. Posteriormente, a estratégia de acúmulo de reservas também passou a ser vista como um indicador do grau de solidez do sistema financeiro doméstico, com efeitos sobre a expectativas dos investidores em relação ao comportamento da taxa de câmbio futura, dos juros e da capacidade de solvência do país frente a suas obrigações financeiras externas (Kaminsky \& Reinhart, 1999). Conforme chamaram a atenção Aizenmann e Lee (2008), surgiram também as abordagens que associam a política de acúmulo de reservas internacionais aos fatores "mercantilistas", cujas reservas são utilizadas para intervir no mercado cambial com o objetivo de manter depreciada a taxa de câmbio e, assim, contribuir para obter superávits comerciais ou nas transações correntes.

Diante do acúmulo de elevados estoques de reservas internacionais nas economias periféricas no início da década de 2000 - e sob um ritmo acelerado -, surgiram diversos trabalhos que passaram a estimar o seu nível ótimo. No Brasil, alguns estudos com base em metodologias alternativas demonstraram que o BCB acumula saldos excessivos de reservas e a contrapartida é a existência de custos não desprezíveis, nos quais se destacam os trabalhos de Cavalcanti e Vonbun (2007); Salomão (2008); Laan et al. (2012); Vonbun (2013); Pelliser et. al (2017) e Pellegrini (2017). 
Vonbun (2013) e Pelliser et. al (2017) estimaram o nível ótimo de reservas para o Brasil com base no modelo proposto por Jeanne e Rancière (2006 e 2011). Ambos concluíram que o nível ótimo de reservas fora ultrapassado a partir de 2006. Em sua estimação, Vonbun (2013) estabeleceu onze cenários em que considerou diferentes padrões de aversão ao risco e custo da crise de balanço de pagamento derivado de uma parada brusca dos fluxos de capitais. Em todos os cenários - incluídos os mais "extremos" que considera níveis dobrados de aversão ao risco e um custo de crise de 12,5\% do PIB - haveria saldos excessivos de reservas e, nos cenários mais cautelosos, observa-se essa tendência no Brasil desde 2010. Salomão (2008) demonstrou que o nível de reservas internacionais para o Brasil apenas pode ser explicado pelo modelo caso considere um custo da crise extremamente elevado, de aproximadamente 20\% do PIB. Pellegrini (2017) considerou doze métricas distintas para determinar níveis prudentes de reservas e todas indicaram saldos excedente de reservas no Brasil em 2017, variando entre US\$ 46,6 bilhões e US\$284,1 bilhões.

O parâmetro Greenspan-Guidotti valeu-se da experiência derivada das crises financeiras dos anos de 1990 e estabeleceu que os países deveriam calibrar suas reservas em relação ao tamanho de sua dívida externa de curto prazo. Assim, o nível ideal de reservas cambiais seria aquele que cobrisse - ao menos - toda a dívida externa de curto prazo do país de até um ano e, adicionalmente, a maturidade média dos passivos deveria ser superior a três anos. Nestes termos, considerou-se que o volume de reservas internacionais adequado é aquele que garante liquidez externa para evitar novos empréstimos nos próximos doze meses. Conforme estabelecido pela metodologia Greespan-Guidotti, um país possui reservas internacionais acima do nível considerado seguro se o indicador obtido pela razão entre reservas cambiais e dívida externa de curto prazo for maior que 1 . Se o resultado for menor que 1 significa que as reservas 
internacionais estão abaixo do volume considerado adequado (Laan, Cunha \& Lélis, 2012; Gollo \& Triches, 2013) ${ }^{2}$.

Gráfico 2 mostra a regra Greespan-Guidotti aplicada ao Brasil de acordo com os dados relativos à dívida externa de curto prazo extraídos do $\mathrm{BCB}^{3}$. $\mathrm{O}$ conceito "restrito" incorpora as operações intercompanhias no índice do BCB e o mesmo indicador é calculado pelo FMI, mas são excluídas tais operações. Ambos os parâmetros revelam que o país já alcançou o índice superior a uma unidade em 2005 e que desde então a economia atingiu o nível considerado seguro caso submetida a uma redução brusca no influxo líquido de capitais. Em meados de 2012 as reservas internacionais foram superiores a quatro vezes a dívida externa de curto prazo, reduzindo essa relação posteriormente devido ao aumento do passivo externo líquido. Considerando a posição das reservas internacionais em dezembro de 2019, de acordo com esta métrica, o Brasil teria um saldo de recursos das reservas excedentes de US\$ 168,1 bilhões segundo o índice calculado pelos dados obtidos do BCB, e de US\$228,5 levando em conta o parâmetro do FMI.

Ponderando o nível de reservas internacionais através do parâmetro GreespanGuidotti expandido, obtido pela dedução da dívida externa de curto prazo o saldo das transações correntes, o Brasil em 2019 teria um saldo de reservas excedentes na ordem de US\$118,7 bilhões - equivalente a 1,5 vezes o volume de ativos externos considerado seguro. Segundo Pellegrini (2017), o objetivo desta métrica é avaliar mais amplamente os compromissos externos de curto prazo do país, sendo maior ou menor em relação a esta métrica a depender do sinal do saldo de transação correntes do balanço de

\footnotetext{
${ }^{2}$ Deve-se ressaltar que grande parte dos instrumentos de dívida externa de longo prazo contêm a cláusula de resgate antecipado (put option), na qual o credor pode exercer o seu direito de ressarcimento, diminuindo o período de amortização da dívida de longo prazo (Carneiro, 2002). Por essa razão, a delimitação da dívida externa de curto prazo convencionalmente aceita pode não refletir a capacidade do país de resistir a uma reversão dos fluxos financeiros de curto prazo como mostra a regra GreespanGuidotti, produzindo um resultado superestimado.

${ }^{3}$ Dívida externa de curto prazo constituída pelo principal e juros vincendos em até um ano (pelo prazo residual). Disponível em: https://www.bcb.gov.br/estatisticas/indicadoresselecionados
} 
pagamentos. Se houver superávit em transações correntes, o indicador expandido é maior que o restrito, e no caso de déficit, será menor. No conceito expandido aplicado ao Brasil, em 2005 o indicador correspondeu a uma unidade e a partir de então oscilou em torno de 2 ao longo de toda a série histórica, exceto entre 2014 e 2016. Os movimentos deste índice corresponderam, principalmente, às variações no saldo de transações correntes, que apresentou déficit desde 2008 e levou a metodologia expandida a uma evolução abaixo da regra Greespan-Guidotti restrita.

\section{Gráfico 2 - Parâmetro Greespan-Guidotti para o Brasil}

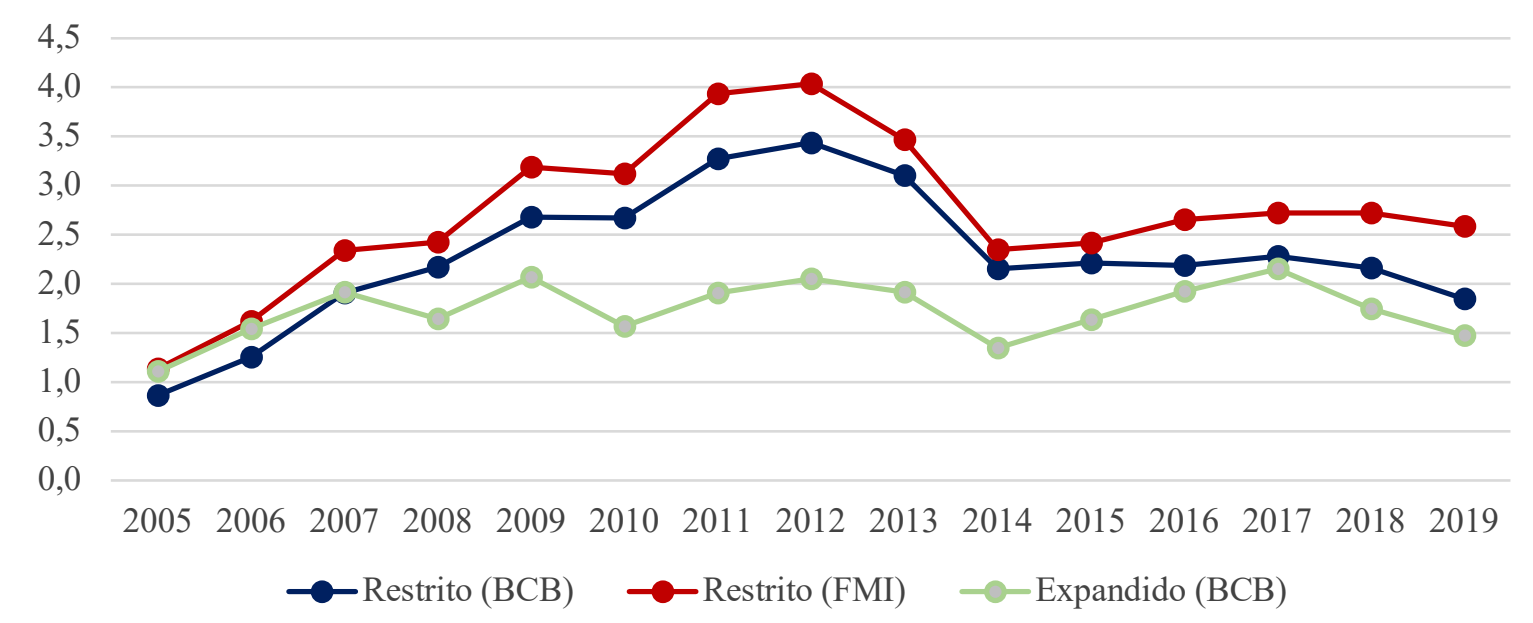

Fonte: Banco Central do Brasil e Fundo Monetário Internacional. Elaboração própria.

Portanto, todos os resultados obtidos pela metodologia Greespan-Guidotti demonstram que as reservas internacionais para o Brasil estão acima do nível considerado adequado em todo o período analisado. Esta mesma constatação é obtida quando se estima as reservas internacionais em relação ao meio de pagamento ampliado, sugerindo também que as divisas acumuladas pelo Brasil estão bem acima do nível apontado como adequado (Gráfico 3).

As reservas internacionais em relação aos meios de pagamento ampliados é uma forma utilizada para definir parâmetros de otimalidade que considera, no caso estimado acima, o agregado monetário M3. Conforme esclarece Pellegrini (2017), o objetivo deste indicador é capturar a possibilidade de saída de capital do país por iniciativa dos 
residentes, atribuído um percentual de $5 \%$ e $10 \%$ do agregado para este fim. De acordo com o Gráfico 3, já em 2002 a relação entre as reservas e o indicador M3 correspondeu a 2 e 4 vezes o saldo equivalente a $5 \%$ e 10\%, respectivamente, aumentando para 4,6 e 2,3 em 2020. O pico verificado em 2015 está associado aos movimentos na taxa de câmbio, atingindo nesse ano os indicadores 6 e 3 ao estimar 5\% e 10\% dos meios de pagamento ampliados. Em 2019, ao considerar 5\% do M3, o Brasil alcançou um saldo excedente de US $\$ 348,0$ bilhões (4,3 vezes o saldo considerado ótimo) e de US \$177,3 bilhões estimando $10 \%$ do M3 (2,1 vezes).

\section{Gráfico 3 - Reservas internacionais em relação ao meio de pagamento ampliado}

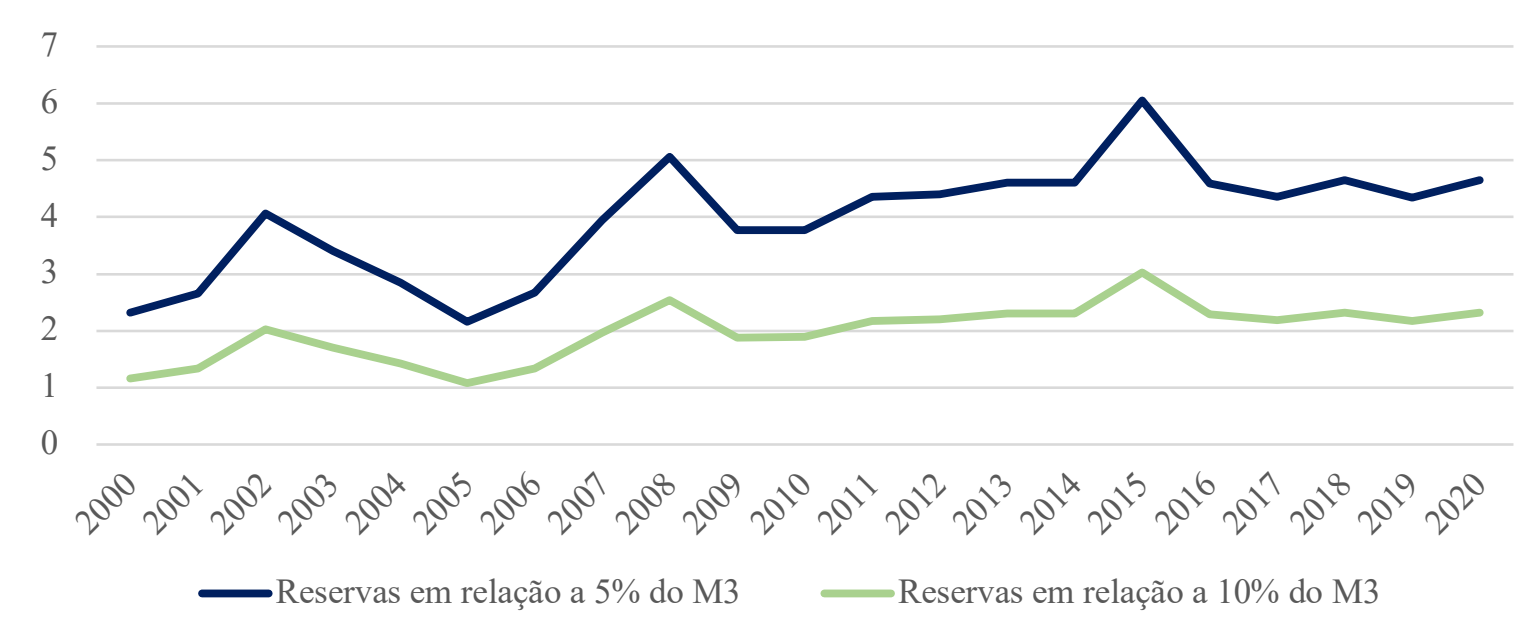

Fonte: Banco Central do Brasil. Elaboração própria.

A metodologia desenvolvida pelo FMI - denominada de Assessing Reserve Adequacy (ARA) e específica para economias emergentes - também revela que o Brasil acumula reservas acima do nível considerado adequado. Esta metodologia considera potenciais pressões cambiais resultantes de choques em quatro componentes do balanço de pagamentos, quais sejam: i) exportação, para captar desequilíbrios da balança comercial decorrentes da queda da demanda externa ou deterioração dos termos de troca, como ocorreu no Brasil durante a crise de 1998/1999; ii) meios de pagamento ampliados, para captar o impacto de uma potencial saída de capital dos residentes por meio da liquidação de ativos domésticos; iii) dívida externa de curto prazo, para 
representar o risco de rolagem associado a esse passivo; e iv) outras obrigações, que reflete outros canais de possíveis perdas de capital, como as aplicações em títulos e ações realizadas por investidores não residentes (FMI, 2010; Pellegrini, 2017).

modelo é concebido a partir do resultado da soma das perdas identificadas em cada componente em períodos de crises cambiais vividas pelos países com diferentes regimes de política cambial (fixo e flutuante). A variável exportação e o estoque de passivos são estimados como percentual de perda durante o ano da crise em relação à média dos três anos antes do evento ocorrer, enquanto a fuga de capital, associada à variação do estoque de ativos domésticos, é calculada como variação percentual do agregado monetário $\mathrm{M} 2$ durante o ano da crise em relação à média de três anos adiante, de modo a corrigir o impacto da apreciação da moeda doméstica (FMI, 2010). As reservas internacionais entre 100\% e 150\% em relação a ARA são consideradas adequadas pelo FMI para fins precaucionais.

Segundo a metodologia proposta pelo FMI, em 2007 o Brasil já havia alcançando o nível mínimo de reservas e já em 2008 superou a ARA acrescida de 50\%. Neste ano, as reservas equivaleram a US\$206.806 bilhões, quando um saldo de US\$ 120.748 bilhões é considerado suficiente para não afetar a sua função precaucional (Gráfico 4). Nos anos seguintes, o indicador sofreu oscilações e um montante maior de reservas foi requerida para ultrapassar o nível adequado, mas, logo em 2015 a métrica acusou 192\% das reservas em relação a ARA, quando o país alcançou US\$ 368.738 bilhões ante US\$ 185.550 necessários, e em 2016 essa relação se reduziu. Em 2018, os ativos externos estiveram 11,1\% acima do parâmetro 150\% da ARA e em 2019 estima-se que o saldo excedente de reservas é de US\$125,3 bilhões para 100\% e US\$ 4,8 para 150\% da ARA. Como mostram os parâmetros estabelecidos pelo FMI, um montante superior ao patamar ótimo não adiciona benefícios marginais à política externa, mas implica custos fiscais adicionais. 
Gráfico 4 - Reservas internacionais totais em relação a ARA para o Brasil

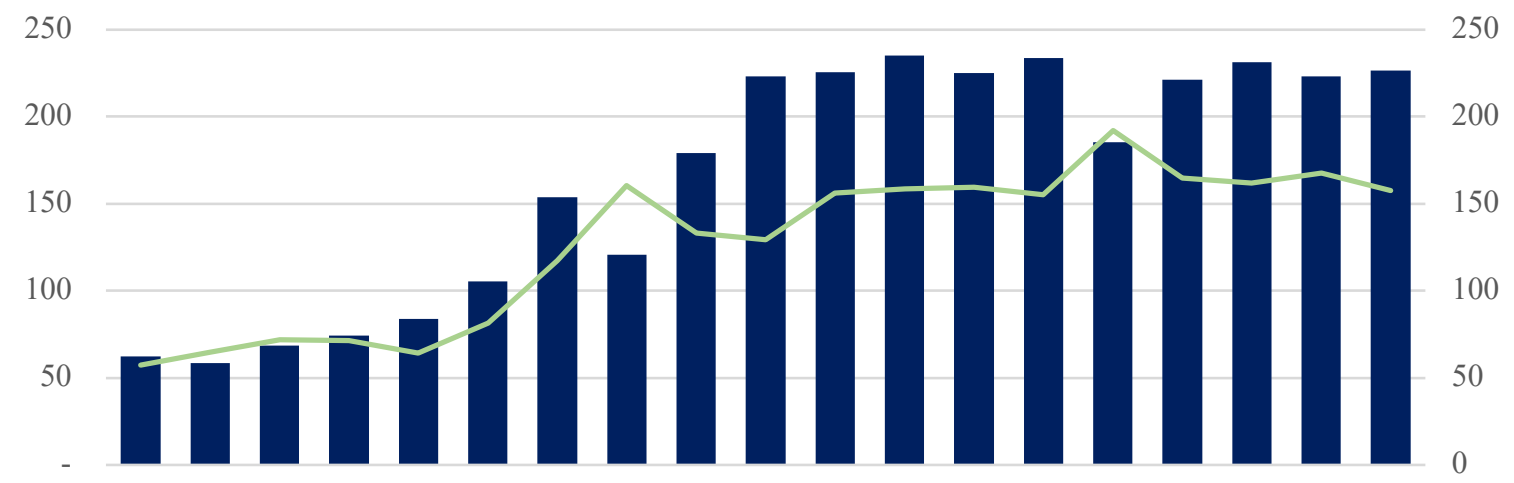

2001200220032004200520062007200820092010201120122013201420152016201720182019

US\$ Bilhões — Porcentagem

Fonte: Fundo Monetário Internacional. Elaboração própria.

$\mathrm{Na}$ Tabela 1 é feita uma síntese sobre os recursos excedente de reservas internacionais contabilizados até 2019 segundo as métricas apresentadas.

Tabela 1 - Posição em 2019 dos recursos excedentes das reservas internacionais

\begin{tabular}{l|l|c|c}
\hline \multirow{2}{*}{ Métricas de adequação das reservas internacionais } & \multicolumn{2}{c}{ Recursos Excedentes das reservas } \\
\cline { 3 - 4 } & & Em US\$ bilhões & Em \% do total \\
\hline Meses de importação & 12 meses de importação & 177.342 & 49,69 \\
\hline \multirow{3}{*}{ Regra Greespan-Guidotti } & Parâmetro Restrito (BCB) & 168.188 & 47,13 \\
& Parâmetro Restrito (FMI) & 228.655 & 64,07 \\
& Parâmetro Expandido (BCB) & 118.736 & 33,27 \\
\hline Meios de pagamento & $5 \%$ do M3 & 348.057 & 97,53 \\
ampliados & $10 \%$ do M3 & 197.336 & 55,29 \\
\hline \multirow{2}{*}{ Assessing Reserve Adequacy } & $100 \%$ & 125.383 & 35,13 \\
& $150 \%$ & 4.886 & 1,37 \\
\hline
\end{tabular}

Fonte: FMI e BCB. Elaboração própria.

O valor mais expressivo é acusado pela metodologia que considera as reservas internacionais em relação a 5\% do M3, gerando um saldo em excesso de US\$348,0 bilhões - correspondente a 97,5\% das reservas totais (Tabela 1). Na estimação das reservas em relação à 10\% do M3, os recursos excedentes seriam de US\$197,3 bilhões (55,2\% do PIB). Já as reservas em excesso ponderadas pelo parâmetro Greespan-Guidotti variam entre US\$188,7 bilhões (33\% do PIB), US\$168, 1 bilhões (47\% do PIB) e US\$ 
228,6 bilhões (64\% do PIB). O resultado menos expressivo é obtido pelo métrica apresentada pelo FMI (150\% da ARA), que estimou um saldo excedente das reservas de US $\$ 4.886$ bilhões equivalente a 1,3\% do montante total das reservas. Vale mencionar que os diferentes resultados dificultam a avaliação da decisão a ser tomada em relação aos recursos excedentes, porque gera dúvida sobre qual parâmetro é considerado adequado sem implicar riscos para o país. Tendo em vista os resultados, sugere-se que a métrica desenvolvida pelo FMI seja a mais conservadora, pois pondera as pressões cambiais resultantes de choques nos quatro principais componentes do balanço de pagamentos.

\section{O debate sobre os recursos cambiais no Brasil}

Em razão da opção pelo ajuste fiscal no Brasil sem aumento de impostos materializado pela EC/95 e da necessidade de expandir os investimentos públicos, o debate sobre o uso das reservas internacionais ganhou força. De um lado, Carneiro e Mello (2017) e Casal Junior (2017) defendem que os ativos externos em excesso poderiam ser destinados à criação de um fundo de investimento, tal como ocorreu na China, Coreia do Sul, Cingapura e entre outros países. Do outro, argumenta-se que os recursos obtidos com a venda dos excedentes de reservas cambiais deveriam abater parte da dívida pública, como fez a Rússia (Bacha, 2016; Goldfajn, 2017; Pellegrini, 2017). No entanto, deve-se levar em conta que o debate sobre utilizar as reservas ganhou força no Brasil em 2016, em face do ajuste fiscal em curso na economia, portanto, são poucos os artigos científicos que subsidiam esta discussão ${ }^{4}$.

Em linha com esse debate, economistas como Edmar Bacha (2016), Pellegrini (2017) e Goldfajn (2017) argumentam que os recursos obtidos com a venda dos ativos externos deveriam abater parte da dívida pública, de modo a reduzir o estoque da dívida

\footnotetext{
${ }^{4}$ Oliveira (2019) faz uma análise mais detalhada sobre a potencial existência de reservas excessivas em posse do Banco Central do Brasil e as propostas de utilização destes recursos para reduzir parte da dívida pública ou para financiar investimentos em infraestrutura.
} 
e os encargos desse passivo. Para Pellegrini (2019, p. 3), "quanto maior o custo [de carregamento das reservas], mais se justifica a estratégia [de vender reservas para abater a dívida bruta do governo geral] e vice-versa". Chachamovitz (2016) recomenda a venda de reservas para abatimento da dívida, desde que esta operação seja realizada "junto a um programa de ajuste fiscal crível, a fim de potencializar os efeitos positivos de curto prazo do ajuste" (p. 355), para que a dívida não volte a crescer posteriormente. Para esta autora, o elevado estoque de reservas internacionais do Brasil constitui um "seguro caríssimo" (p. 351) expresso por seu custo de carregamento.

Tendo em vista que existem critérios distintos para que se apure o que é exatamente o "excesso" de reservas, Pellegrini (2017) propõe utilizar um montante que seja compatível com todos os parâmetros, e sugere, a título de uma experiência inicial, o uso de US\$ 60 bilhões a partir da qual seriam observados os resultados. Ele ainda defende que a venda de parte dos ativos externos, assim como outros possíveis ativos potencialmente alienáveis, deve ser acompanhada por um ajuste fiscal ou - conforme propuseram Garcia (2018) e Gottlieb (2018) - pela aprovação da Reforma da Previdência ${ }^{5}$, de modo a garantir o controle do endividamento público. Nessa mesma perspectiva, Bacha $(2016)^{6}$ salientou que "o pior dos mundos seria usar as reservas para aumentar as despesas correntes do governo, porque estaríamos trocando um ativo valioso por um gasto temporário". Mesmo que os recursos fossem destinados às despesas de capital - mecanismo que aumenta a demanda interna de imediato, assim como as despesas correntes - o autor argumenta que não seria uma medida razoável, uma vez que as reservas acabariam e os investimentos não se sustentariam a longo prazo.

\footnotetext{
${ }^{5}$ A Emenda Constitucional da reforma da previdência foi promulgada em novembro de 2019 com o objetivo, segundo o governo, de reduzir o déficit nas contas da Previdência Social. Para mais detalhes, acesse o link: http://www.brasil.gov.br/novaprevidencia/

${ }^{6}$ Artigo publicado no jornal $\bigcirc$ Globo em 2016. Disponível em: https://oglobo.globo.com/opiniao/paunas-reservas-que-ma-ideia-18452365
} 
Contrapondo-se a esta proposta - e assumindo a crítica de ter ela motivações puramente "fiscalistas" -, Carneiro e Mello (2017) propuseram utilizar o excedente de reservas no financiamento a projetos de investimento, variável que tem sido sacrificada nos episódios de ajuste fiscal, especialmente após a introdução do Novo Regime Fiscal nos marcos da Emenda Constitucional 95, que limita a expansão da despesa primária à inflação do ano anterior.

Com base neste cenário e na constatação dos elevados custos de carregamento das reservas internacionais, Carneiro e Mello (2017) - e posteriormente difundido por Casal Junior (2017) - propuseram criar um fundo de investimento em infraestrutura com aporte inicial dos recursos cambiais excedentes. Embora os autores argumentem que esta proposta tem um objetivo mais amplo - como o de "auxiliar mais decididamente o crescimento econômico no que tange a um tema crucial: o financiamento do investimento" -, ela é apresentada apenas no plano conceitual e pouca informação é dada sobre a sua operacionalização. Carneiro $(2018)^{8}$ reconhece que "o próprio autor se declara desconhecedor dos detalhes da proposta" e, por esta razão, são discutidas apenas as linhas gerais de sua implementação.

O fundo proposto seria de propriedade do Tesouro Nacional e os recursos cambiais depositados inicialmente seriam gradativamente convertidos em moeda nacional, de modo a minimizar os impactos sobre a base monetária e taxa de câmbio. Em artigo mais recente, Carneiro (2018) esclareceu que os recursos cambiais seriam vendidos pelo Banco Central ao Tesouro Nacional e convertidos em real, sendo o pagamento da transferência realizado com a Conta Única através da rubrica "remuneração das disponibilidades". Os recursos depositados no fundo seriam subscritos em títulos emitidos pelo setor privado, as denominadas debêntures de

\footnotetext{
${ }^{7}$ Artigo publicado no Jornal GGN em 2017. Disponível em: https://jornalggn.com.br/noticia/as-reservasinternacionais-e-os-mitos-da-ortodoxia-por-ricardocarneiro-e-guilherme-mello

8 Artigo publicado no jornal Le Monde Diplomatique Brasil em 2018. Disponível em: https://diplomatique.org.br/reservas-internacionais-e-financiamento-do-investimento/
} 
infraestrutura, e constituiriam um ativo seguro à medida que são lastreados no fluxo de caixa dos projetos e contam com garantia adicional de fundos garantidores. A taxa de retorno desses títulos poderia se situar ligeiramente acima da taxa Selic, segundo a descrição de Carneiro e Mello (2017), inicialmente instituído com caráter fechados, mas com possibilidade posteriormente de ter cotas negociadas com o público e passar a receber financiamento do setor privado. Ademais, após a consolidação do fundo poderia ocorrer a saída do Tesouro Nacional enquanto gestor dos recursos, podendo resultar em ganhos de capital como consideram os autores.

Uma das dimensões favoráveis dessa medida diz respeito à alavancagem da atividade econômica, ao implantar um programa que contemple o financiamento de 50\% do Banco Nacional de Desenvolvimento Econômico e Social (BNDES), 30\% de captação de recursos provenientes da emissão de debêntures de infraestrutura subscritos pelo novo fundo e 20\% de capital próprio (Carneiro \& Mello, 2017).

Embora a substituição dos títulos do Tesouro americano pelos títulos domésticos não implique redução do estoque da dívida pública no seu conceito líquido, esta medida é neutra em relação aos impactos sobre o montante de endividamento do governo. Por outro lado, o custo de rolagem da dívida pública como um todo seria reduzido em razão da substituição de parte das reservas internacionais pelos ativos do fundo a vencer no futuro (com rentabilidade substancialmente maior), reduzindo a taxa implícita obtida pela diferença entre os juros pagos sobre os passivos do setor público (Selic) e os juros recebidos pelos ativos.

Carneiro e Mello (2017) concluem que tal proposta, além de dinamizar o crescimento econômico por meio do investimento em um setor estratégico da economia e "melhorar" as finanças públicas, contribui para o desenvolvimento do mercado de capitais, através da consolidação de um instrumento financeiro peculiar e, adicionalmente, abre campo para maior envolvimento do setor privado no financiamento de longo prazo. Devido a essas dimensões favoráveis, entende-se que "a 
constituição deste fundo é uma forma adequada de financiar o investimento, gerando uma fonte de demanda autônoma que não pressiona a dívida pública, e ao diminuir a carga líquida de juros, reduz o déficit público" 9 .

A proposta de criação de um fundo de investimento em infraestrutura com aporte das reservas internacionais, de recursos do BNDES e do setor privado foi incorporada ao Plano de Governo (2019-2022) da coligação PT, PCdoB e PROS nas eleições presidenciais de 2018, que lançou a candidatura de Fernando Haddad ${ }^{10}$. A despeito do fundo proposto por Carneiro e Mello (2017), o Brasil perdeu sua posição no grupo de países que investem no mercado doméstico e mundial por meio de fundos de riqueza soberana, ao extinguir em março de 2018, por decisão do presidente Michel Temer, o Fundo Fiscal de Investimento e Estabilização (FFIE) criado em 2008. Este fundo foi instituído com a finalidade de "promover investimentos em ativos no Brasil e no exterior, formar poupança pública, mitigar os efeitos dos ciclos econômicos e fomentar projetos de interesse estratégico do País localizados no exterior" (STN, 2018, p. 6). Os recursos, até então depositados na Conta Única do Governo em um montante total de $\mathrm{R}$ \$,64 bilhões, serão destinados ao cumprimento da meta de resultado primário estabelecida na Lei de Diretrizes Orçamentárias (LDO) de 2018 enquanto um esforço para reduzir a dívida pública federal segundo divulgado pelo Ministério da Fazenda em sua página oficial.

\section{Para além dos custos de carregamento das reservas: o que a experiência brasileira recente aponta}

Segundo as métricas apontadas na seção anterior, o Banco Central do Brasil estaria operando com estoques de reservas internacionais muito além de sua principal

\footnotetext{
${ }^{9}$ Artigo publicado no Jornal GGN em 2017. Disponível em: https://jornalggn.com.br/ noticia/as-reservas-internacionais-e-os-mitos-da-ortodoxia-por-ricardocarneiro-e-guilherme-mello

${ }^{10}$ Plano de Governo (2019-2022) da coligação PT, PCdoB e PROS. Disponível em: https://pt.org.br/wpcontent/uploads/2018/08/plano-de-governo_haddad-13-pdf.pdf
} 
função de mitigação de uma crise financeira nas contas externas. A contrapartida dessa política é a existência de elevados custos.

Para o FMI (2010, p. 8), "large reserve accumulation has significant opportunity costs for the accumulating countries, and in aggregate may have a systemic deflationary impact". Nessa perspectiva, reservas internacionais em excesso podem causar impactos deflacionários agregados devido a busca pelos países em manter superávits em conta corrente - por não estarem mais dispostos a incorrer em déficits no balanço de pagamentos - implicando medidas protecionistas e desvalorizações competitivas. Pode ainda comprometer a qualidade dos estoques representados por esses ativos ao promover um fluxo excessivo de risco e de capital volátil, além de gerar preocupações em torno da acumulação ser concentrada predominantemente em uma determinada moeda e expor todo o sistema a choques que surgem nas economias emissoras das reservas.

No debate especificamente doméstico, reservas cambiais excessivas carregam implicações negativas, pois geram custos não desprezíveis derivados dos elevados diferenciais entre os juros interno e externo. Um aumento nas reservas efetivamente tem como contrapartida o aumento da dívida pública. Tais intervenções ocorrem através da venda de títulos ou pela emissão de títulos público em moeda doméstica, os quais pagam juros para absorver o excesso de liquidez na economia. Em termos práticos, a expansão da base monetária que decorreria da compra de reservas internacionais é drenada por essa operação, permanecendo inalterada a taxa básica de juros ${ }^{11}$.

\footnotetext{
${ }^{11}$ A literatura convencional chama essas operações de esterilização, que precisariam ser realizadas para impedir o suposto impacto inflacionário decorrente da expansão da base monetária (ver, por exemplo, Bacen, 2003). Ocorre, porém, que a simples gestão do regime de metas inflacionárias com uma taxa de juros básica definida exogenamente pelo Banco Central exige a emissão de dívida pública como contrapartida do aumento da base monetária, sob pena de desviar a taxa básica de juros da meta de juros compativel com a meta inflacionária. São, portanto, operações de caráter compensatório (Serrano \& Pimentel, 2017).
} 
No Brasil, considerando que a alocação por moeda das reservas internacionais é feita principalmente em dólar norte-americano (82,3\%), a compra do ativo denominado em dólar é realizada a uma baixa remuneração e o custo fiscal pago pelas reservas é a diferença entre a taxa de retorno dos títulos do Tesouro americano e a taxa de juros básica brasileira (Selic). Deve-se notar que este é o custo mínimo incorrido pelo governo federal, pois como as reservas são aplicadas no mercado internacional, a apuração em reais incorpora a flutuação da taxa de câmbio entre a moeda doméstica e estrangeira, logo, é adicionado a este custo a variação cambial. A parte superior da tabela 2 a seguir mostra que tais custos são bastante significativos.

Os dados relativos ao custo de manutenção das reservas internacionais totais elaborados com base nos relatórios de gestão de reservas internacionais do Banco Central do Brasil -, mostram que em 2003 o Tesouro gastou 1,2\% do PIB (US\$ 6,7 bilhões ou R $\$ 23,8$ bilhões) para carregar o saldo de US\$49,2 bilhões em reservas, correspondente a um custo de financiamento de 13,75\% associado aos diferenciais de remuneração dos títulos públicos em relação às taxas de remuneração em dólar. A redução do custo de carregamento entre o período de 2005 a 2007 se deveu à combinação da diminuição da taxa Selic e aumento do rendimento das reservas. Entre 2008 e 2012, este custo foi de US\$16,830 bilhões ( $\$$ \$ 30,2 bilhões) para manter as reservas (0,08\% do PIB) e em 2013 os custos foram maiores decorrentes da rentabilidade negativa dos investimentos de $-1,46 \%$, ou custo de US $\$ 36,3$ bilhões ( $\$$ 78,508 bilhões correspondentes a 1,47\% do PIB). Em 2015, o processo de acumulação de reservas resultou no custo fiscal de 3,04\% do PIB (US\$ 54,8 bilhões), reduzindo para 2,76\% do PIB em 2016 (US\$ 49,5 bilhões) e 1,43\% em 2017 (US\$29,2 bilhões). Em reais, o custo médio de manutenção dos ativos externos no triênio 2015-2017 foi de R \$ 149,7 bilhões, já em 2019 o custo das reservas caiu para 0,42\% (US\$ 5,9 bilhões) - devido principalmente a uma melhora nos diferenciais de juros. 
Entretanto, tais custos não podem ser avaliados em absoluto, pois as reservas internacionais proporcionam blindagem externa, e seus benefícios transcendem a natureza puramente fiscal e são objetivamente mais difíceis de mensurar. Por outro lado, esta blindagem não é necessariamente proporcional ao próprio estoque de reservas. Como vimos na seção anterior, a partir de um nível considerado ótimo de reservas a economia não se encontra necessariamente mais blindada, mas assume custos fiscais esses sim diretamente proporcionais ao estoque de reservas -, sempre que houver um diferencial positivo entre a taxa que remunera os passivos decorrentes das reservas (dívida pública) e a taxa que remunera as reservas, e sempre que houver apreciação da moeda doméstica, estando o setor público na posição de credor líquido em moeda estrangeira. Todavia, abaixo do nível supostamente ótimo de reservas, assume-se que os custos fiscais são mais que compensados pelos benefícios da blindagem externa e, mais do que isso, são inevitáveis. A literatura que debate o nível ótimo de reservas lastreia o debate brasileiro sobre o que fazer com as reservas supostamente excedentes, cujos custos fiscais podem, esses sim, ser evitados. Assume-se, na abordagem aqui proposta, uma assimetria: os custos fiscais abaixo do nível ótimo de reservas são inevitáveis, já que o objetivo é assegurar a blindagem externa; mas como acima do nível ótimo não há blindagem externa excedente, ou é desprezível, então o custo fiscal poderia ser evitado. Por este motivo, a parte inferior da tabela 2 propõe o cálculo do custo das reservas excedentes como um conceito mais adequado para tratar deste problema.

Os custos relativos ao carregamento das reservas excedentes, expressos na parte inferior da Tabela 2, foram estimados utilizando como parâmetro a metodologia de adequação das reservas do FMI. As avaliações de adequação dos ativos externos foram colocadas diretamente no contexto da vigilância desta instituição e, em razão desse compromisso, o conceito do FMI é considerado mais conservador em relação às demais metodologias apresentadas na seção dois deste artigo. Além de ser uma métrica elaborada especificamente para os países emergentes, em sua estrutura analítica leva-se em conta choques e vulnerabilidades sobre cinco componentes do balanço de 
pagamento - exportação, meios de pagamento ampliados, dívida externa de curto prazo e outras obrigações.

Posto isso, com base nos resultados calculados pela métrica reserva em relação à 100\% da ARA, entre 2002 e 2006, o Brasil ainda não possuía ativos excedentes, e por este motivo os custos foram estimados somente a partir de 2007, quando o BCB registrou um saldo de US\$26,6 bilhões superior ao considerado pelo FMI como adequado. Entre 2007 e 2010, os custos fiscais em proporção do PIB foram pouco significativos, situando em torno de 0,05\% do PIB em média (US\$ 5,2 bilhões ou R \$9,7 bilhões). A partir de 2011, os custos tornaram-se crescentes e atingiram em 2015 1,45\% do PIB (US $\$ 25,8$ bilhões ou R \$ 85,8 bilhões), 1,16\% em 2016 (US\$ 20,7 bilhões ou R \$ 72,4 bilhões), e reduziram para $0,66 \%$ do PIB no ano seguinte (US\$13,6 bilhões ou R $\$$ 43,5 bilhões).

No biênio 2018-2019, os custos associados ao carregamento das reservas excedentes, em média, foram ainda menores, de 0,51\% do PIB - equivalente a US $\$ 7,9$ bilhões. Este movimento de alta e posterior redução do custo guarda forte correlação com o ciclo da taxa Selic, que aumentou a partir de meados de 2012 até meados de 2017, quando atingiu seu ápice no ciclo recente, e passou a cair. Por outro lado, este custo não representa uma parcela majoritária da despesa com juros do setor público consolidado, tendo representado 5,9\% entre 2007 e 2010, e 10,7\% entre 2011 e 2014, e 15,2\% entre 2015 e 2017. 
Tabela 2 - Custo das reservas totais e das reservas excedentes

\begin{tabular}{|c|c|c|c|c|c|c|}
\hline \multirow[b]{2}{*}{ Ano } & \multicolumn{6}{|c|}{ Custo das Reservas Totais } \\
\hline & $\begin{array}{c}\text { Reservas } \\
\text { Internacionais em } \\
\text { US\$ Bilhões }\end{array}$ & $\begin{array}{c}\text { Rentabilidade } \\
\text { em (\%) }\end{array}$ & $\begin{array}{c}\text { Financiamento em } \\
(\%)\end{array}$ & $\begin{array}{l}\text { Custo em } \\
\text { US\$ } \\
\text { Bilhões }\end{array}$ & $\begin{array}{c}\text { Custo em } \\
\text { R\$ }\end{array}$ & $\%$ PIB \\
\hline 2002 & 39.594 & 8,30 & 10,87 & 4.305 & 12.576 & 0,84 \\
\hline 2003 & 49.296 & 9,60 & 13,75 & 6.776 & 20.858 & 1,21 \\
\hline 2004 & 52.935 & 5,02 & 11,23 & 5.943 & 17.388 & 0,89 \\
\hline 2005 & 53.799 & $-3,60$ & 22,65 & 12.185 & 29.674 & 1,37 \\
\hline 2006 & 85.839 & 6,00 & 9,08 & 7.791 & 16.955 & 0,70 \\
\hline 2007 & 180.334 & 9,40 & 2,48 & 4.465 & 8.697 & 0,32 \\
\hline 2008 & 206.806 & 9,35 & 3,13 & 6.476 & 11.880 & 0,38 \\
\hline 2009 & 239.054 & 9,37 & 0,56 & 1.344 & 2.686 & 0,08 \\
\hline 2010 & 288.575 & 1,82 & 7,94 & 22.907 & 40.321 & 1,04 \\
\hline 2011 & 352.012 & 3,60 & 8,02 & 28.235 & 47.292 & 1,08 \\
\hline 2012 & 378.613 & 1,84 & 6,65 & 25.190 & 49.236 & 1,02 \\
\hline 2013 & 375.794 & $-1,46$ & 9,68 & 36.386 & 78.508 & 1,47 \\
\hline 2014 & 374.051 & $-0,64$ & 11,54 & 43.182 & 101.622 & 1,76 \\
\hline 2015 & 368.739 & $-1,60$ & 14,87 & 54.825 & 182.651 & 3,04 \\
\hline 2016 & 372.221 & 0,70 & 13,32 & 49.575 & 173.019 & 2,76 \\
\hline 2017 & 381.972 & 2,27 & 7,67 & 29.295 & 93.509 & 1,43 \\
\hline 2018 & 379.722 & 1,17 & 5,25 & 19.943 & 72.876 & 1,17 \\
\hline \multirow{2}{*}{2019} & 366.376 & 4,33 & 1,62 & 5.920 & 23.357 & 0,42 \\
\hline & \multicolumn{6}{|c|}{ Custo das Reservas Excedentes* } \\
\hline Ano & $\begin{array}{l}\text { Saldo em US\$ } \\
\text { Bilhões }\end{array}$ & $\begin{array}{c}\text { Rentabilidade } \\
\text { em (\%) }\end{array}$ & $\begin{array}{c}\text { Financiamento em } \\
(\%)\end{array}$ & $\begin{array}{l}\text { Custo em } \\
\text { US\$ } \\
\text { Bilhões }\end{array}$ & $\begin{array}{l}\text { Custo em } \\
\text { R\$ }\end{array}$ & $\% \mathrm{PIB}$ \\
\hline 2002 & -18.746 & $-3,93$ & 23,10 & -4.331 & -12.651 & $-0,85$ \\
\hline 2003 & -19.072 & $-3,71$ & 27,06 & -5.161 & -15.886 & $-0,92$ \\
\hline 2004 & -21.313 & $-2,02$ & 18,27 & -3.893 & -11.392 & $-0,58$ \\
\hline 2005 & -32.928 & 2,20 & 16,85 & -5.547 & -13.508 & $-0,62$ \\
\hline 2006 & -19.536 & $-1,37$ & 16,44 & -3.212 & -6.990 & $-0,29$ \\
\hline 2007 & 26.660 & 1,39 & 10,49 & 2.796 & 5.445 & 0,20 \\
\hline 2008 & 86.058 & 3,89 & 8,59 & 7.393 & 13.563 & 0,44 \\
\hline 2009 & 60.038 & 2,35 & 7,58 & 4.550 & 9.090 & 0,27 \\
\hline 2010 & 65.499 & 0,41 & 9,34 & 6.121 & 10.774 & 0,28 \\
\hline 2011 & 126.545 & 1,29 & 10,33 & 13.068 & 21.888 & 0,50 \\
\hline 2012 & 143.615 & 0,70 & 7,80 & 11.195 & 21.882 & 0,45 \\
\hline 2013 & 150.735 & $-0,59$ & 8,81 & 13.277 & 28.647 & 0,54 \\
\hline 2014 & 140.117 & $-0,24$ & 11,14 & 15.615 & 36.747 & 0,64 \\
\hline 2015 & 183.188 & $-0,79$ & 14,06 & 25.762 & 85.827 & 1,43 \\
\hline 2016 & 151.038 & 0,28 & 13,73 & 20.744 & 72.400 & 1,16 \\
\hline 2017 & 150.702 & 0,90 & 9,04 & 13.629 & 43.504 & 0,66 \\
\hline 2018 & 138.729 & 0,43 & 6,42 & 8.909 & 32.556 & 0,52 \\
\hline 2019 & 117.285 & 1,39 & 5,95 & 6.974 & 27.512 & 0,50 \\
\hline
\end{tabular}

Nota: (*) segundo o critério do FMI, ver seção 2.

Fonte: Banco Central do Brasil - Relatório de gestão de reservas internacionais (vários anos). Elaboração própria. 
Há ainda que se considerar o gerenciamento das reservas internacionais por meio do uso de swaps cambiais realizadas pelo BCB nos últimos anos, levantando questões sobre a escolha pelas autoridades monetárias em preservar os estoques de reservas utilizando este dispositivo. Segundo a definição do $\mathrm{BCB}^{12}$, swap é um derivativo financeiro que promove a troca de risco e rentabilidade de ativos financeiros entre agentes econômicos durante o período especificado no contrato. $\bigcirc$ objetivo dessa operação é prover proteção cambial aos agentes econômicos contra a volatilidade da taxa de câmbio e fornecer liquidez ao mercado cambial doméstico. Dessa forma, o BCB se compromete a pagar ao detentor do swap a variação do dólar em relação ao real do período contratado acrescida de uma taxa de juros (cupom cambial), enquanto o mercado se compromete a pagar a taxa Selic. Se a soma da depreciação da moeda com o cupom cambial for maior que a Selic no período o BCB paga ao mercado a diferença, e se for menor o mercado é quem paga ao Banco Central.

A partir de 2013 as operações de swap passaram a ser utilizadas com maior intensidade no Brasil, como mostra o valor nocional expresso no Gráfico 5. O aumento de tais operações em 2013 está associado à necessidade de "provide hedge opportunities to market participants indebted in foreign currency, preserving the financial stability of the economy" (Macalós, 2020, p. 120). O instrumento também tem como objetivo evitar flutuações excessivas da taxa de câmbio (Pellegrini, 2019) e reduzir sua volatilidade, estabelecendo limites informais de flutuação, embora sua eficácia neste quesito seja sempre objeto de muita controvérsia - ver, por exemplo, Prates (2015). Conforme Ribeiro (2016, p. 33), essas operações "substituem uma intervenção direta no mercado de câmbio na forma de venda de dólares à vista, evitando-se o uso das reservas internacionais do país". De acordo com Pellegrini (2017), canalizar as reservas para o mercado cambial para atender a demanda equivalente ao valor nocional em dólar das operações de swaps ocorreria apenas em situação limite. Isto porque usar reservas por

12 A definição de swap cambial encontra-se na página oficial do BCB no link https://www.bcb.gov.br/estabilidadefinanceira/swapcambial 
proteção no mercado cambial implicaria depreciação da moeda nacional, como também, a compra de ativos externos obriga a dar um destino para essas divisas.

Gráfico 5 - Reservas internacionais: valor bruto, valor nocional dos swaps com reservas, e posição líquida (reservas menos valor nocional dos swaps) (US\$ bilhões)

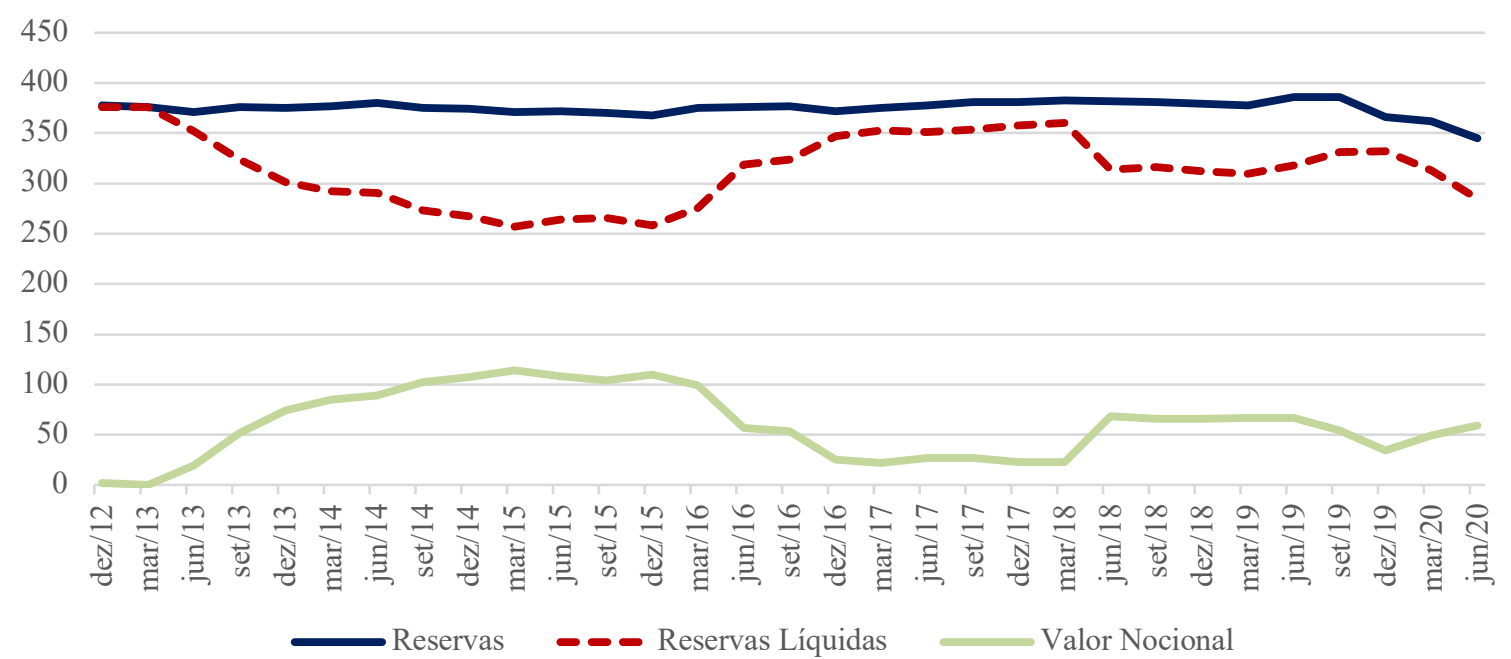

Fonte: Banco Central do Brasil. Elaboração própria.

O Gráfico 5 ainda mostra a evolução das reservas líquidas dos swaps - obtidas pela subtração dos ativos externos as operações de swap cambiais. Nestes termos, as reservas internacionais líquidas em 2014 corresponderiam a US\$ 266,0 bilhões (equivalente a uma redução de US\$ 107,9 bilhões das reservas totais) e em 2015 a redução seria de US\$110,244 bilhões. Já em 2016, as reservas líquidas seriam de US\$ 346,715 bilhões, contra US\$372,221 bilhões sem contabilizar as operações de swaps, em 2017 a redução dos ativos chegaria a US\$23,796 bilhões e a partir de 2018 as reservas internacionais se reduziriam ainda mais em resposta às oscilações cambiais.

Para Ribeiro (2016, p. 33), aparentemente este mecanismo gera uma perda de reservas, mas na prática os swaps não produzem impacto direto ou indireto sobre o estoque das reservas do país porque são operações liquidadas em moeda nacional. Quando a soma da depreciação da moeda com cupom cambial supere a Selic, a perda do Banco Central com essas operações é registrada como um pagamento de juros 
líquidos por parte do setor público, mas quando o oposto ocorre, o ganho do BCB gera receita de juros líquidos para o setor público (Barbosa-Filho, 2018). Como este balanço de ganhos e perdas impacta a despesa de juros, ela afeta também o resultado nominal, com contrapartida na dívida pública. Barbosa-Filho (2018) estimou que entre 2003 e 2014 os ganhos ou perdas com swaps cambiais equivaleram a valores entre -0,49 e 0,30\% do PIB, mas em 2015 saltaram para 1,5\% do PIB, quase 1/5 da despesa de juros líquidos do setor público, mas em 2016 a reversão da depreciação do real gerou ganhos equivalentes a $1,21 \%$ do PIB.

As operações de swaps, assim como a política de acúmulo de reservas tendo como contrapartida a emissão de dívida mobiliária interna de custo elevado face a um ativo externo de baixa rentabilidade, contribuem para o aumento do custo da DLSP, expresso pela taxa de juros implícita que capta a média das taxas de juros incidentes sobre os ativos e passivos da dívida pública (BCB, 2016). A taxa implícita incidente sobre a dívida pública será tanto maior quanto maior for a diferença entre os juros pagos sobre os passivos do setor público (Selic) e a remuneração dos ativos; quanto maior for a participação das reservas internacionais nos ativos financeiros do setor público; quanto maior for a SELIC dos anos imediatamente anteriores; e quanto maior for a relação entre dívida bruta e a dívida líquida (Gentil \& Araujo, 2012). Entre 2012 e 2014, o custo da DLSP saiu de uma média de $16,6 \%$ para quase $30 \%$ ao final de 2015 , quando as operações de swaps atingiram o valor nocional de $\mathrm{R} \$ 426,770$ bilhões (Gráfico 6). déficit nominal cresceu mais de 4\% do PIB de 2014 para 2015, passando de 6\% para 10,2\%, resultando no aumento da DLSP em 3 pontos percentuais segundo os dados oficiais do BCB. Embora entre 2016 e 2020 a dívida pública tenha se elevado em proporção do PIB, seu custo de carregamento diminuiu para 18\% ao final de 2016, 14\% em 2017 e chegou a 9,6\% em abril de 2020 - conforme os dados do BCB. 


\section{Gráfico 6 - Evolução da taxa implícita da DLSP e da Selic (em \%)}

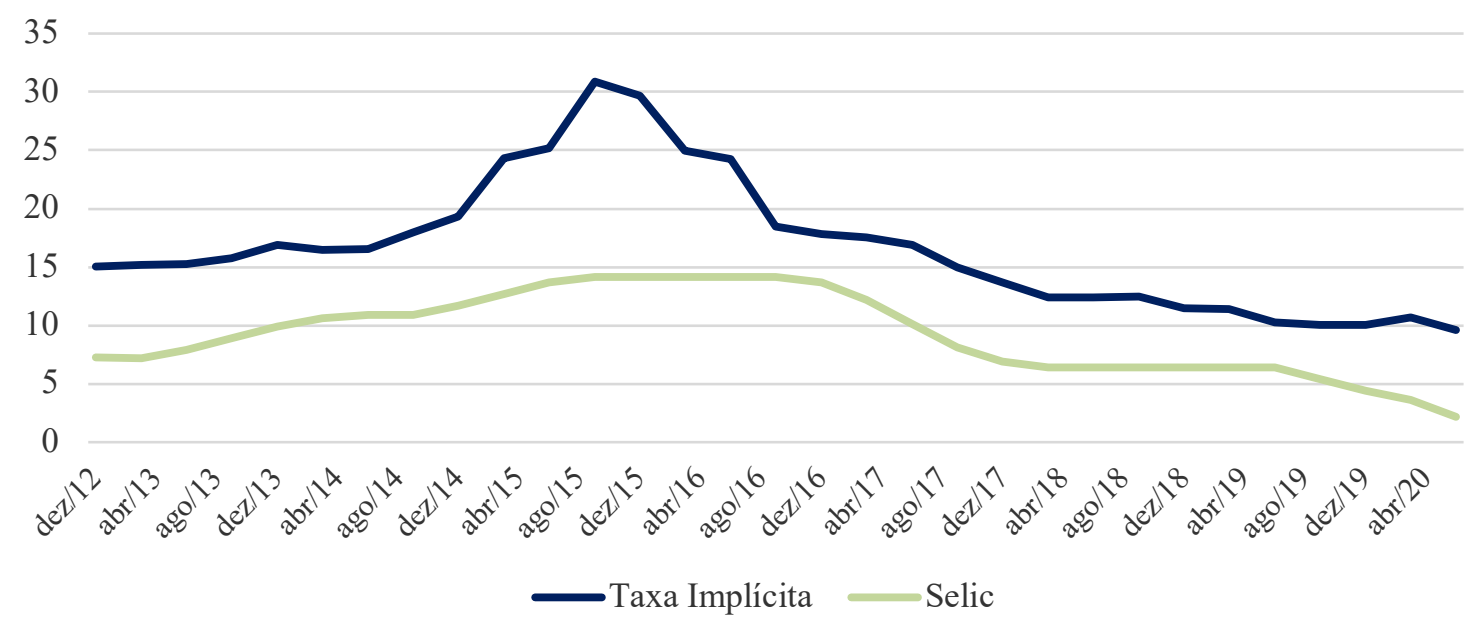

Fonte: Banco Central do Brasil. Elaboração própria.

Por outro lado, o debate sobre custo das reservas internacionais (excedentes ou totais), quando colocado exclusivamente nos termos de seu custo de carregamento costuma desconsiderar as especificidades que regulam o relacionamento entre o Tesouro Nacional e o Banco Central do Brasil. As desvalorizações cambiais, ao valorizar os ativos externos quando convertidos em reais, inflam o resultado financeiro do Banco Central; as valorizações cambiais, por sua vez, desvalorizam os ativos externos quando convertidos em reais, e reduzem o resultado financeiro do BCB. Até 2019, quando o $\mathrm{BCB}$ registrava resultados positivos, devia transferi-los à Conta Única do Tesouro, enquanto os resultados negativos deviam ser cobertos pelo Tesouro na forma de emissão de títulos em favor do BCB. Entre 2008 e 2018, o BCB transferiu ao Tesouro R\$ 709,2 bilhões a título de equalização cambial, enquanto a União transferiu ao BCB R\$ 695,4 bilhões, na forma de emissões diretas do Tesouro para a carteira do BCB (Brasil Secretaria do Tesouro Nacional, 2019). Ainda que o saldo líquido positivo fosse baixo e insuficiente para cobrir o custo decorrente do diferencial de taxas de juros, a reversão da trajetória de apreciação do real entre 2011 e 2015 tornou mais frequentes os episódios de ganhos financeiros transferidos ao Tesouro, além de tê-los ampliado (Gráfico 7). Por outro lado, a apreciação do real ocorrida entre 2016 e 2017 levou à ocorrência de 
resultados negativos. A maior volatilidade dos resultados financeiros do BCB ensejou uma modificação deste arcabouço legal em 2019, quando a Lei 8.320 instituiu mecanismos para que parte desses ganhos oriundos das desvalorizações cambiais fosse convertido em reservas contábeis no próprio BCB para cobrir perdas futuras decorrentes da apreciação da moeda doméstica, reduzindo as transferências ao Tesouro. A intenção alegada era reduzir a volatilidade dos resultados financeiros do BCB (BRASIL - Secretaria do Tesouro Nacional, 2019).

Tabela 3 - BCB: resultados financeiros oriundos da equalização cambial ( $\mathrm{R} \$$ milhões)

\begin{tabular}{cccccc}
\hline Semestre/ano & Principal & Atualização & Semestre/ano & Principal & Atualização \\
\hline $1^{\circ} / 2008$ & $(44.798)$ & $(2.776)$ & $2^{\circ} / 2013$ & 15.919 & 311 \\
$2^{\circ} / 2008$ & 171.416 & 3.550 & $1^{\circ} / 2014$ & $(51.224)$ & $(2.349)$ \\
$1^{\circ} / 2009$ & $(93.787)$ & $(3.355)$ & $2^{\circ} / 2014$ & 65.173 & 1.559 \\
$2^{\circ} / 2009$ & $(53.932)$ & $(1.402)$ & $1^{\circ} / 2015$ & 46.407 & 1.102 \\
$1^{\circ} / 2010$ & $(1.893)$ & $(111)$ & $2^{\circ} / 2015$ & 110.938 & 2.782 \\
$2^{\circ} / 2010$ & $(46.637)$ & $(6.114)$ & $1^{\circ} / 2016$ & $(184.645)$ & $(11.072)$ \\
$1^{\circ} / 2011$ & $(46.199)$ & $(2.956)$ & $2^{\circ} / 2016$ & $(55.674)$ & $(6.087)$ \\
$2^{\circ} / 2011$ & 90.240 & 1.779 & $1^{\circ} / 2017$ & $(15.745)$ & $(802)$ \\
$1^{\circ} / 2012$ & 32.210 & 544 & $2^{\circ} / 2017$ & $(30.677)$ & $(3.016)$ \\
$2^{\circ} / 2012$ & $(9.901)$ & $(1.103)$ & $1^{\circ} / 2018$ & 146.201 & 2.994 \\
$1^{\circ} / 2013$ & 15.767 & 296 & $2^{\circ} / 2018$ & $(19.134)$ & $(1.718)$ \\
\hline
\end{tabular}

Fonte: Secretaria do Tesouro Nacional (2019).

É importante esclarecer que as tabelas 2 e 3 lidas em conjunto expressam custos fiscais de naturezas distintas. $\bigcirc$ conceito de custo de carregamento expresso na tabela 2 refere-se ao diferencial de taxas de juros incidentes sobre as reservas internacionais convertido em reais (e, portanto, também impactado pela variação cambial) e a dívida 
pública correspondente a ela. Já os resultados da equalização cambial se aplicam ao estoque de reservas internacionais. Neste último caso, a tabela 3 mostra a intercalação entre perdas e ganhos sempre que, a despeito da trajetória de longo prazo da taxa de câmbio, circunstancialmente se observam reversões de curto prazo, quando também se intercalam valorizações e desvalorizações cambiais.

\section{Gráfico 7 - Resultados financeiros do $\mathrm{BCB}$ oriundos da equalização cambial ( $\mathrm{R} \$$ milhões, eixo direito) e taxa de variação cambial (média anual, \%, eixo esquerdo)}

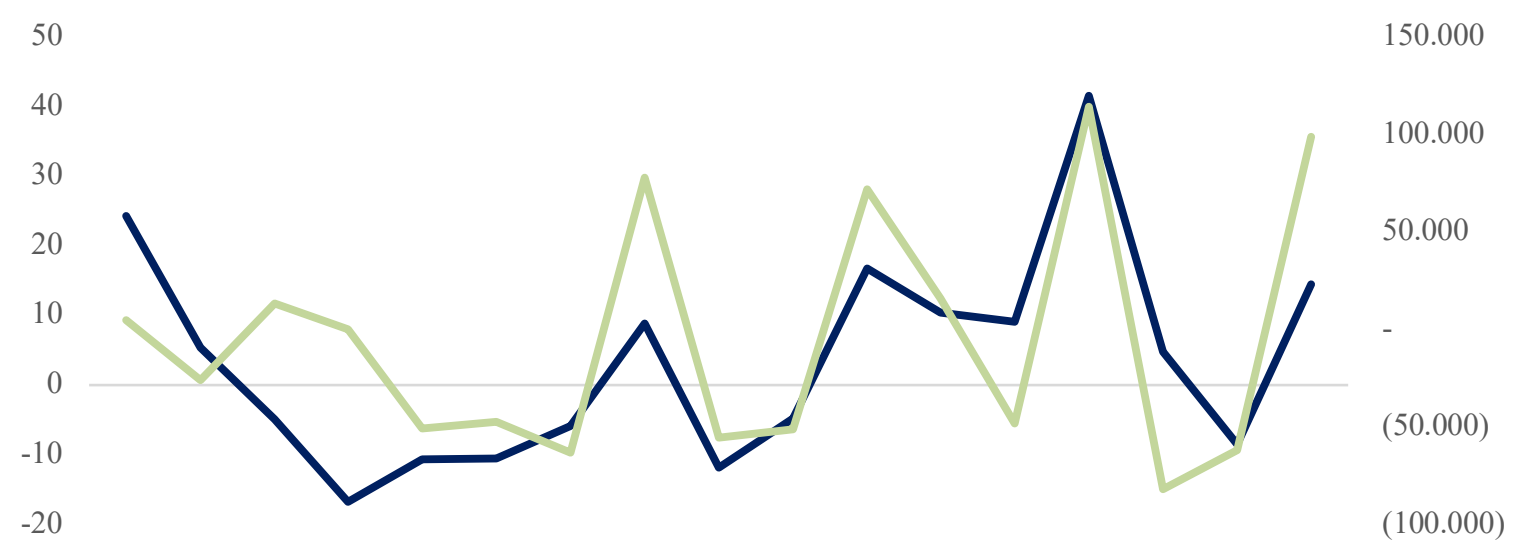

20022003200420052006200720082009201020112012201320142015201620172018

— variação cambial nominal (\%)

resultado financeiro BCB (reservas)

Fonte: Ipeadata e Secretaria do Tesouro Nacional. Elaboração própria.

Metodologicamente, não se pretende aqui propor uma análise de custos fiscais totais associados às reservas internacionais, mas propor mediações necessárias ao debate que, como vimos, no Brasil parece centrar demasiadamente no argumento do custo de carregamento como inspiração de propostas de venda (e do que fazer com o produto dessa venda) do suposto excedente de reservas internacionais.

Outra mediação necessária quando o debate é travado em sua dimensão estritamente fiscal deve considerar também a trajetória da dívida líquida do setor público devido a sua composição (em especial a dívida externa líquida) e aos impactos da trajetória da taxa de câmbio. Cabe aqui esclarecer o porquê da importância da dívida líquida do setor público enquanto indicador utilizado aqui como referência nos 
parágrafos que se seguem. Como explicitado em Silva e Medeiros (2009), o conceito de dívida líquida é usualmente utilizado para medir os riscos de solvência do setor público, enquanto o de dívida bruta mede o risco de sua rolagem. Trata-se de um indicador tradicionalmente utilizado de saúde das finanças públicas ${ }^{13}$, a partir de uma equação básica que relaciona o crescimento da dívida líquida ao resultado primário, à despesa com juros incidente sobre o estoque da dívida, à taxa de juros e à taxa de crescimento do PIB (quando a dívida líquida é medida como proporção deste último) ${ }^{14}$. No Brasil, as metas de resultado primário do setor público têm como objetivo estabilizar ou reduzir a DLSP/PIB. O indicador registrou queda expressiva entre 2004 e 2013, mas as operações de empréstimo do Tesouro Nacional ao Banco Nacional de Desenvolvimento Econômico e Social (BNDES) realizadas entre 2008 e 2014, no total de R 436 bilhões (Dweck \& Teixeira, 2018), ensejaram um debate a respeito da inadequação do conceito de dívida líquida do setor público como indicador de solvência, já que os empréstimos do Tesouro ao Banco, por sua natureza, não poderiam ser utilizados para abater a dívida. Por este motivo, a literatura sobre finanças públicas passou a dar mais centralidade, ou ao menos incorporar também, o conceito de dívida bruta ${ }^{15}$. Entretanto, as devoluções antecipadas de aproximadamente $\mathrm{R} \$ 379$ bilhões entre 2015 e 2019, parecem atestar a fragilidade desse argumento ${ }^{16}$. Por este motivo, a análise a seguir priorizará o conceito de dívida líquida.

\footnotetext{
${ }^{13}$ Inúmeros trabalhos sobre finanças públicas no Brasil utilizam a dívida líquida entre os principais indicadores como objeto de análise: Giambiagi (2008), IPEA (2009), Gentil e Araujo (2012), Gentil e Hermann (2017), Barbosa-Filho (2015 e 2018).

${ }^{14}$ Ver, por exemplo, Bastos, Rodrigues e Lara (2015).

${ }^{15}$ A este respeito, ver por exemplo Ferreira (2016), Dweck e Teixeira (2018), Gobetti \& Schettini (2014).

$16 \bigcirc$ conceito de dívida líquida, a despeito das complexidades metodológicas que envolvem a sua mensuração, tem como vantagem a simplicidade daquilo que procura mensurar: quanto sobra de dívida se os ativos financeiros forem liquidados para abatê-la. Trata-se, claro, de um conceito, já que a liquidação dos ativos e a posterior liquidação da dívida envolve operações e efeitos complexos sobre a gestão da liquidez da economia que não constituem objeto deste trabalho, e por este motivo, não se espera na prática que os ativos sejam de fato liquidados. Contudo, o conceito supõe algum grau de liquidez entre os ativos que são deduzidos da dívida bruta para a mensuração da dívida líquida. Como o BNDES realiza empréstimos de longo prazo a partir dos recursos emprestados do Tesouro, supunha-se que dificilmente
} 
As desvalorizações cambiais têm um efeito benigno sobre as finanças públicas sob as condições vigentes após 2007, quando o setor público consolidado se tornou credor líquido em moeda estrangeira, ao passo que os episódios de valorizações cambais deterioram as finanças públicas. Medida em moeda doméstica, os passivos e ativos em moeda estrangeira quando convertidos em reais sofrem o impacto dos episódios de depreciação e apreciação da moeda. Na condição vigente até 2007, em que o setor público consolidado era devedor líquido em moeda estrangeira, as crises cambiais de 1999 e 2002 provocaram a elevação da DLSP/PIB, ensejando políticas de ajuste fiscal, viabilizadas por meio de aumento da carga tributária (IPEA, 2009). Já após 2007, na condição em que o setor público se tornou credor líquido em moeda estrangeira - já que o estoque de reservas internacionais se tornou superior à dívida externa do setor público - os episódios de depreciação do real tiveram efeito contrário, reduzindo a DLSP/PIB. Em 2008, por exemplo, a redução da DLSP/PIB abriu espaço fiscal para a adoção de políticas contracíclicas (IPEA, 2009).

A tabela 4 a seguir apresenta a evolução da DLSP e seus fatores condicionantes, medidos como percentagem do PIB. Os episódios de depreciação do real ocorridos em 2008 e após 2011 contribuíram para a redução da DLSP/PIB. Após 2015, o aumento da despesa com juros e o déficit primário mais do que compensaram os impactos do ajuste cambial, e por este motivo a DLSP passou a descrever trajetória altista, o que não invalida a relação estabelecida aqui.

Historicamente, no Brasil, os episódios de depreciação "rápida e acentuada" da moeda doméstica (Bresser-Pereira, 2009, p. 26) se contrapõem aos episódios de apreciação mais suave e duradoura da moeda nacional. A importância das reservas internacionais está na possibilidade de enfrentamento desses episódios. É claro que nem toda depreciação da moeda doméstica é rápida e acentuada. O Brasil, após 2011, parece

esses ativos poderiam ser liquidados para abatimento da dívida. Mas a devolução antecipada de parte desses empréstimos atestou, a nosso juízo, a fragilidade deste argumento, ainda que a devolução tenha sido utilizada para outras finalidades que não o abatimento estrito senso da dívida. 
ter revertido a longa trajetória de apreciação do real em curso desde $2003^{17}$. Esta reversão, contudo, não impediu a sequência de episódios de depreciação do real rápidas e acentuadas - ocorridos em 2015, 2018 e 2020.

A assimetria existente entre desvalorizações rápidas e acentuadas e valorizações suaves e duradouras geram impactos distintos sobre a economia brasileira e sobre as finanças públicas. Nas condições que vigoravam antes de 2007, quando o setor público consolidado era devedor líquido em moeda estrangeira, as desvalorizações deterioravam a DLSP e, sob a vigência e recomendação das práticas de gestão do regime de política macroeconômica, a resposta se dava na forma de metas de superávit primário maiores, normalmente por uma combinação de aumento da carga tributária e redução/controle do gasto. Após 2007, na condição de credor líquido, a depreciação do real passou a reduzir a DLSP/PIB, não sendo mais necessário elevar as metas de superávit primário. Foi precisamente o que ocorreu na crise de 2008-9, quando a resposta à crise do subprime se deu na forma de redução do superávit primário e redução de impostos, sem comprometer o gasto público (IPEA, 2009). A posterior reapreciação do real tornou a elevar a DLSP/PIB, mas aos patamares pré-depreciação da moeda, sem determinar uma trajetória de elevação, já que ela voltou a cair nos anos seguintes.

Tabela 4 - Fatores condicionantes para o crescimento da DLSP (em \% PIB)

\begin{tabular}{ccccccc|c}
\hline \multicolumn{7}{c|}{ Necessidade de Financiamento do Setor Público } & \\
\cline { 1 - 4 } Ano Primário & $\begin{array}{c}\text { Juros } \\
\text { Nominais }\end{array}$ & $\begin{array}{c}\text { Resultado } \\
\text { Nominal }\end{array}$ & $\begin{array}{c}\text { Ajuste } \\
\text { Cambial }\end{array}$ & $\begin{array}{c}\text { Efeitos da var. do } \\
\text { PIB }\end{array}$ & Outros & DLSP \\
\hline 2003 & $-3,2$ & 7,6 & 4,4 & 9,8 & $-8,0$ & 0,9 & 54,3 \\
2004 & $-3,2$ & 8,4 & 5,2 & $-3,8$ & $-6,6$ & 0,6 & 50,2 \\
2005 & $-3,7$ & 6,6 & 2,9 & $-0,9$ & $-4,9$ & 0,0 & 47,9 \\
2006 & $-3,2$ & 6,7 & 3,6 & $-0,3$ & $-4,8$ & 0,0 & 46,5 \\
2007 & $-3,2$ & 6,0 & 2,7 & 0,8 & $-5,3$ & $-0,2$ & 44,5 \\
2008 & $-3,3$ & 5,3 & 2,0 & $-2,5$ & $-5,6$ & $-0,9$ & 37,6 \\
& & & & & & &
\end{tabular}

${ }^{17}$ As causas desta reversão não constituem objeto do presente trabalho, mas podem ser lidas em Prates et al. (2014), Prates (2015) e Barbosa-Filho (2015). 


\begin{tabular}{lllllll|l}
2009 & $-1,9$ & 5,1 & 3,2 & 2,4 & $-2,5$ & 0,2 & 40,9 \\
2010 & $-2,6$ & 5,0 & 2,4 & 0,5 & $-5,8$ & 0,0 & 38,0 \\
2011 & $-2,9$ & 5,4 & 2,5 & $-1,5$ & $-4,2$ & $-0,2$ & 34,5 \\
2012 & $-2,2$ & 4,4 & 2,3 & $-1,2$ & $-3,1$ & $-0,2$ & 32,2 \\
2013 & $-1,7$ & 4,7 & 3,0 & $-1,8$ & $-3,1$ & 0,3 & 30,5 \\
2014 & 0,6 & 5,4 & 6,0 & $-1,7$ & $-2,0$ & 0,2 & 32,6 \\
2015 & 1,9 & 8,4 & 10,2 & $-6,4$ & $-1,2$ & 0,4 & 35,6 \\
2016 & 2,5 & 6,5 & 9,0 & 3,2 & $-1,5$ & $-0,1$ & 46,2 \\
2017 & 1,7 & 6,1 & 7,8 & $-0,2$ & $-2,1$ & $-0,1$ & 51,6 \\
2018 & 1,6 & 5,5 & 7,1 & $-2,5$ & $-2,1$ & 0,0 & 53,6 \\
\hline
\end{tabular}

Nota: Outros = privatizações + reconhecimento de dívidas + outros ajustes na dívida externa. Fonte: Banco Central do Brasil.

Após 2011, quando a moeda doméstica interrompeu a longa trajetória de apreciação, seus efeitos sobre a DLSP/PIB foram sentidos na forma de uma sistemática contribuição para a sua redução - exceto, claro, em 2016, quando prevaleceu um movimento de apreciação do real, compensando a brusca depreciação da moeda doméstica de 2015. Contudo, a partir deste ano, este efeito passou a ser mais que compensado por outras forças que contribuíram para o crescimento da DLSP/PIB, como a despesa com juros, cujo efeito foi majoritário, e o déficit primário.

Por este motivo, claro está que as reservas internacionais não blindam a economia brasileira somente no front externo, mas também no front interno, no que diz respeito às finanças públicas. Isto ocorre porque, depois que o setor público consolidado assumiu a condição de credor líquido em moeda estrangeira, a dívida líquida do setor público, indicador que consolida ativos e passivos em moeda doméstica e estrangeira, cai nos momentos críticos representados pelas crises que desencadeiam desvalorizações cambiais rápidas e acentuadas. Neste sentido, o argumento que advoga a existência de um nível ótimo de reservas que assegure a blindagem externa a partir do qual as reservas adicionais são consideradas excedentes e portadoras de um custo fiscal não se aplica à blindagem que as reservas fornecem às finanças públicas. Esta blindagem ocorre quando a dívida pública não está exposta às variações cambiais, em particular aos episódios de desvalorizações rápidas e acentuadas da taxa de câmbio, e pode ocorrer por uma 
combinação de redução da dívida pública mobiliária atrelada à variação cambial e a posição credora liquida do setor público em moeda estrangeira. É importante ressaltar que blindagem é um termo que se aplica a condições excepcionais, e não às condições consideradas normais. Seus custos são permanentes, mas seus benefícios somente são sentidos especialmente ${ }^{18}$ nos momentos críticos: os de depreciação rápida e acentuada da moeda doméstica. Porém, somente no front externo pode fazer sentido a ideia de um nível ótimo de reservas, a partir do qual não haveria blindagem adicional. No front interno, reservas adicionais sempre reduzirão mais a DLSP/PIB nos episódios de depreciação rápida e acentuada da moeda doméstica, oferecendo alívio fiscal e permitindo as condições para acomodar políticas fiscais anticíclicas ${ }^{19}$.

Deste modo, no frontinterno não faz sentido falar em reservas excedentes. Ainda assim, oferecemos no Gráfico 8 um exercício que compara os benefícios das reservas sobre a DLSP/PIB e o custo de carregamento das reservas excedentes. Os benefícios são calculados sobre as reservas totais porque, como argumentamos acima, qualquer reserva adicional proporciona redução adicional da DLSP/PIB nos episódios de depreciação da moeda doméstica, bem como aumenta a DLSP/PIB nos episódios de apreciação da moeda nacional. Entretanto, só faz sentido calcular o custo fiscal sobre as reservas consideradas excedentes, já que o argumento fiscalista não recomenda se desfazer de todas as reservas, mas somente do excesso.

\footnotetext{
${ }^{18}$ Ainda que não exclusivamente, já que, como vimos anteriormente, trajetórias de depreciação suaves e duradouras da moeda doméstica, como ocorrido entre 2011 e meados de 2014, também tiveram efeitos de redução da relação DLSP/PIB.

${ }^{19}$ Nos termos da Teoria Monetária Moderna - discutidos, por exemplo, em Wray (2003) -, regras fiscais que limitam o crescimento do gasto público, do déficit público ou da dívida pública constituem restrições auto-impostas, já que em Estados que emitem soberanamente sua moeda e determinam a taxa básica de juros as restrições para a expansão do gasto público são reais (como a ociosidade de fatores de produção ou a restrição externa), e não financeiras. Todavia, se existem as restrições auto-impostas, que no Brasil são representadas por normativos como a EC/95, a Regra de Ouro, a Lei de Responsabilidade Fiscal, e as metas de resultado primário estabelecidas em lei, a queda da relação DLSP/PIB decorrente das desvalorizações cambiais rápidas e acentuadas abre espaço fiscal para acomodar políticas anticíclicas. $\bigcirc$ ano de 2020 constitui exceção, quando foi admitida a ruptura de todas aquelas regras em caráter excepcional em nome do enfrentamento da pandemia.
} 
Gráfico 8 - Impacto do ajuste cambial e do custo das reservas excedentes (em \% PIB)

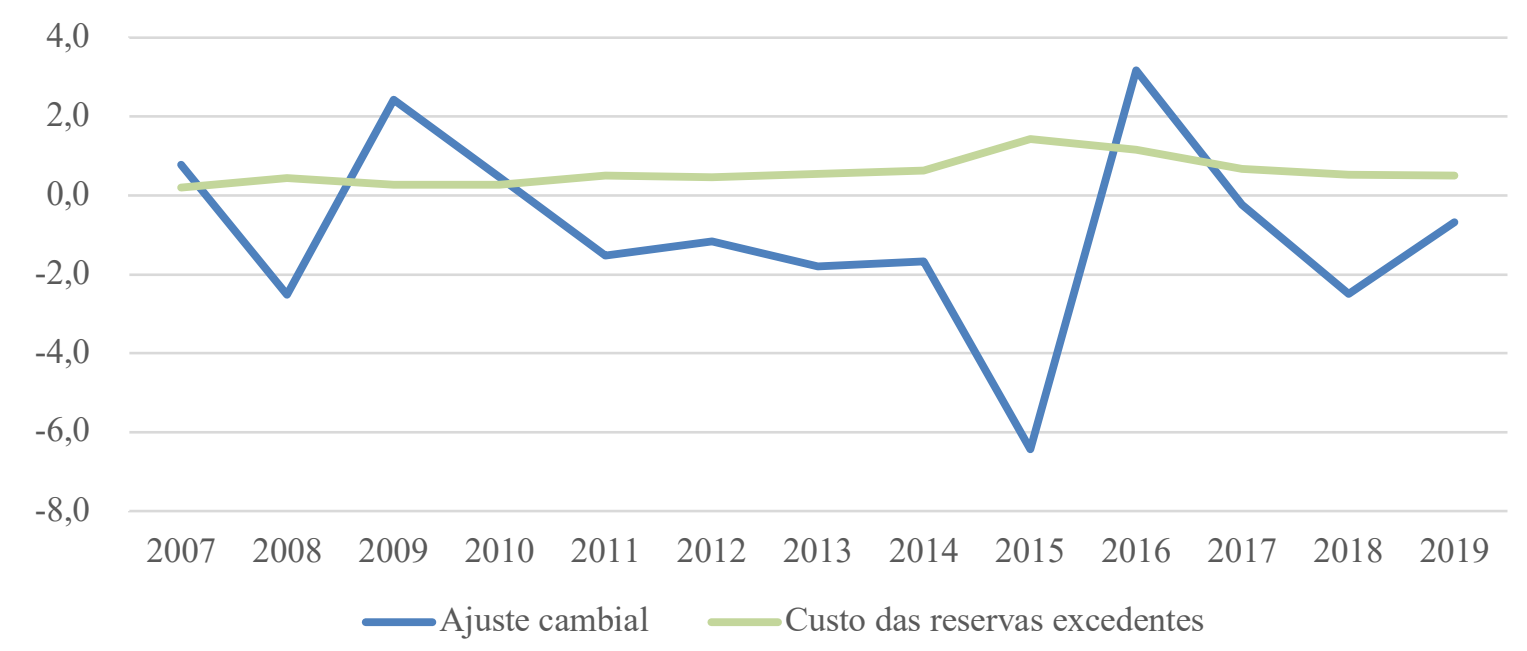

Fonte: Banco Central do Brasil. Elaboração própria.

A trajetória da DLSP está relacionada também aos efeitos contábeis que a política de acúmulo de reservas exerce sobre o endividamento público de acordo com as flutuações da taxa de câmbio. O sentido dependerá da condição, credora ou devedora líquida, em moeda estrangeira. A partir de 2007, quando o setor público brasileiro se tornou credor líquido em moeda estrangeira, nas fases de apreciação cambial há um aumento da dívida líquida provocado pela depreciação dos ativos externos. Em contrapartida, nos episódios de depreciação da moeda doméstica ocorre redução da DLSP devido à apreciação das reservas. É importante notar que a condição de credor líquido em moeda estrangeira protegeu as finanças públicas dos efeitos de crises cambiais que, até 2002, provocavam brutal deterioração dos indicadores fiscais, e exigiam aumento das metas de superávit primário - para estabilizar a DLSP/PIB ou colocá-la em trajetória de queda - que normalmente era obtido com aumento de carga tributária (IPEA, 2009). Como observamos no Gráfico 8, que mensura o impacto do ajuste cambial nos fatores condicionantes da DLSP, os ajustes cambiais mais que compensaram os custos das reservas excedentes, com destaque para o ano de 2015 quando o ajuste cambial contribuiu para uma redução de 6,4\%. Notadamente, neste 
mesmo ano registrou-se o maior custo do excedente de reservas em proporção do PIB, o equivalente a 1,4\%. De modo geral, com exceção dos anos de 2015 e 2016 nos quais o custo das reservas excedentes alcançou em média 1,3\% do PIB, a participação dos ativos externos em excesso na DLSP não foi tão significativa ao considerar que os custos anuais foram, em média, 0,4\% do PIB. Ademais, somente em 2009 e em 2016 os custos das reservas excedentes foram superiores ao impacto dos ajustes cambiais sobre a redução da razão DLSP/PIB.

Como apontam Gentil e Araújo (2012, p. 14), é imperativo constatar que os custos relativos à manutenção de reservas são mensuráveis e duradouros, enquanto os benefícios são circunstanciais e mensurá-los, "a fim de confrontar com os custos fiscais, não é tarefa simples e objetiva, porque encerra forte conteúdo subjetivo em termos do que se preservou como decorrência da redução da instabilidade macroeconômica". Por ora sabe-se que, em um contexto macroeconômico de apreciação cambial, os benefícios marginais decrescem para níveis altos de reservas em função do ônus fiscal que incide sobre o endividamento público. Contudo, em um cenário de depreciação cambial não haveria limites do benefício de reduzir contabilmente a DLSP.

\section{Considerações finais}

$\bigcirc$ presente artigo pretendeu contribuir para o debate a respeito da conveniência ou não de utilizar os recursos obtidos pelas reservas internacionais ditas excedentes do Brasil na expansão do investimento ou no abatimento da dívida pública. Cabe aqui destacar alguns apontamentos sobre esta discussão: i) apesar do elevado nível de reservas internacionais em posse do BCB e dos custos fiscais associados à essa política, os ativos externos atuam como um seguro contra a instabilidade cambial causada por eventos externos e/ou internos e ainda restam dúvidas sobre o eventual montante que poderia ser utilizado sem afetar essa função precaucional; ii) embora exista diversas métricas para definir o nível ótimo de reservas, ainda não se definiu uma metodologia 
universalmente aceita, e assim, algumas métricas podem ser mais ou menos apropriadas a depender das circunstâncias de cada país; iii) restam dúvidas também acerca da necessidade de acumular estoques excessivos, levando em conta que, na crise financeira de 2008, o uso das reservas foi bem mais modesto do que o suposto necessário em um cenário de interrupção dos fluxos de capitais. Tendo em vista tais incertezas, derivadas da própria limitação do estudo sobre a adequação de reservas, é importante tratar este tema com bastante cautela.

Ademais, a contribuição das reservas internacionais para mitigar as crises externas é de duas naturezas. A primeira delas, amplamente debatida pela literatura econômica, considera as reservas como um colchão de liquidez em moeda internacional para enfrentar as crises cambiais e, como tal, possui um determinado valor considerado "ótimo", abaixo do qual a economia estaria desprotegida de algum evento externo provocador de "sudden stop", mas acima da qual a proteção, já adequada, significa apenas custos fiscais crescentes. Aqui, vale ressaltar, a contribuição das reservas reside na proteção a esta circunstância específica. Porém, há uma segunda natureza, pouco ressaltada na literatura econômica, associada à blindagem que as reservas internacionais oferecem às finanças públicas. No Brasil, em que o setor público se encontra na posição de credor líquido em moeda estrangeira, desvalorizações cambiais reduzem a dívida líquida do setor público, e não há limites para este efeito - quanto maior for o estoque de ativos externos em comparação com a dívida externa (ou seja, quanto maior for a dívida externa líquida do setor público), maior será o impacto das crises cambais na melhora da DLSP/PIB. Obviamente, na reversão da depreciação da moeda doméstica também se observará o efeito contrário, de elevação da DLSP/PIB à medida em que a taxa de câmbio se revaloriza. Mas nunca é demais lembrar que reservas internacionais existem não para os momentos de calmaria e normalidade econômica, mas exatamente para enfrentar as turbulências internacionais. Mas, para além desta circunstância específica, este resultado também é válido para os momentos em que a taxa de câmbio se desvaloriza por efeitos diversos, como por exemplo, de trajetórias mais longas de 
reversão da política monetária nos países centrais causadoras de depreciação das moedas periféricas. Foi o que ocorreu no Brasil entre 2011 e 2014, quando o real se depreciou e contribuiu para reduzir a DLSP em aproximadamente 1,5 pontos percentuais ao ano. E em 2015, após a depreciação rápida e acentuada da moeda doméstica ocorrida naquele ano, a posição credora em moeda estrangeira contribuiu para reduzir a relação DLSP/PIB em 6,5 pp-mas este efeito foi mais que compensado pela despesa com juros decorrente do aumento da taxa Selic e das operações com swap cambiais realizadas naquele ano. Por este motivo (ou critério), o recomendado seria preservar a totalidade das reservas internacionais.

Vale mencionar que, em 2008 quando o Brasil acumulou mais de US $\$ 206$ bilhões em reservas, um dos principais instrumentos para mitigar os impactos da crise externa foi uma política fiscal que combinou desonerações e ampliação do gasto, e redução da meta de superávit primário. Mas, isto somente foi possível porque a depreciação do Real reduziu a DLSP, abrindo espaço fiscal segundo a lógica das regras fiscais adotadas no Brasil. Na antiga condição de devedor líquido em moeda estrangeira, a depreciação da moeda nacional elevava a DLSP e a resposta se dava na forma de aumento do superávit primário e da carga tributária. Em 2008, sob a condição de credor líquido em moeda estrangeira, a depreciação do real reduziu a DLSP e permitiu a redução do superávit primário. Isto nos leva à importante constatação de que o custo de carregamento não deve ser o principal critério a nortear a estratégia de acúmulo de reservas. Por outro lado, outros instrumentos de política econômica devem ser usados de forma coordenada para compor a estratégia de gerenciamento externo do país, visando reduzir a dependência e a vulnerabilidade externa. Por este motivo, é importante reforçar que sob a adoção de argumentos puramente fiscais não é possível defender a venda do excesso de reservas internacionais, qualquer que seja este montante, já que a blindagem que elas proporcionam para a dívida pública ainda recomenda que elas sejam preservadas em sua totalidade. Neste sentido, o mais recomendado seria preservar o estoque de reservas internacionais. 
Ainda que esta possibilidade exclua as alternativas em debate para o uso de parte das reservas para o abatimento da dívida pública ou para o financiamento do investimento público, algumas considerações ainda merecem ser feitas. A primeira é que abater dívida pública é algo que só faz sentido ao se assumir que o conceito de dívida bruta é mais relevante do que o de dívida líquida como parte integrante dos indicadores de finanças públicas. Por outro lado, esta medida requer sintonia para balancear as necessidades de liquidez da economia, a trajetória da taxa de câmbio e sua volatilidade.

A proposta de financiamento do investimento público utilizando parte das reservas também merece algumas considerações. A formulação original da proposta ainda se encontra no terreno conceitual, com pouco detalhamento de sua execução. A proposta sugere a criação de um fundo de investimento fomentado pela parte das reservas internacionais considerada excedente, mas pouco se sabe como exatamente ocorreria a transferência das reservas do BCB para o fundo de investimento que inicialmente será de propriedade do Tesouro. Outro problema é que a proposta parece ter sido formulada para driblar - e, portanto, conviver - com os diversos constrangimentos impostos ao gasto público em geral, e ao investimento em particular. De todos os constrangimentos, o mais recente é a Emenda Constitucional 95, mas também há outros, como a chamada regra de ouro (artigo 167 da Constituição Federal de 1988) e a Lei Complementar nº 101 (Lei de Responsabilidade Fiscal). Além desses constrangimentos legais, há ainda outro, de natureza também política, porém discricionária, que é a meta de redução ou estabilização da relação dívida/PIB por meio de metas de resultado primário (positivo entre 1999 e 2013). Embora as metas de resultado primário por si só não impeçam a realização de políticas fiscais anticíclicas (como já observamos durante o ano de 2009), a atuação deste instrumento fica bastante limitada, uma vez que os gastos públicos e, principalmente os investimentos, tornam-se subordinados ao compromisso maior de obter a meta de resultado primário. Ademais, se a trajetória da relação dívida/PIB sofre o efeito das despesas com juros e do ajuste cambial, controlá-la apenas por meio do resultado primário constitui escolha política, e 
não técnica. Neste sentido, é recomendável uma maior coordenação entre os diferentes instrumentos da política macroeconômica se o objetivo perseguido for a estabilização da relação dívida/PIB.

Neste sentido, uma agenda de pesquisa (e de proposição de políticas) que procure sustentar teórica e empiricamente a flexibilização ou a revogação dos dispositivos legais que amarram a política fiscal, bem como as escolhas políticas que a norteiam, nos parecem mais promissoras se a intenção for reabilitar o investimento público.

\section{Referências}

Aizenman, J., \& Lee, J. (2008), Financial versus monetary mercantilism: Long-run view of large international reserves hoarding. World Economy, 31(5), 593-611. doi: https://doi.org/10.1111/j.1467-9701.2008.01095.x

Bacha, E. (2020, janeiro 12), Pau nas reservas? Que má ideia. Jornal O Globo, Caderno Opinião. Recuperado a partir de https://oglobo.globo.com/opiniao/pau-nasreservas-que-ma-ideia-18452365

Banco Central do Brasil. Sistema Gerenciador de Séries Temporais. Recuperado a parti de

https://www3.bcb.gov.br/sgspub/localizarseries/localizarSeries.do?method=pr epararTelaLocalizarSeries.

Banco Central do Brasil. (2016), Relatório anual do Banco Central do Brasil. Recuperado a partir

de https://www.bcb.gov.br/htms/novaPaginaSPB/Relat\%C3\%B3rio\%20Anual\% 20do\%20STR\%20\%202016.pf.

Banco Central do Brasil (2021), Relatório de gestão das reservas internacionais. Recuperado a partir de https://www.bcb.gov.br/estabilidadefinanceira/relgestaoreservas 
Barbosa-Filho, N. (2015), O desafio macroeconômico de 2015-2018. Revista de Economia Política, 35(3), p. 403-425. doi: http://dx.doi.org/10.1590/010131572015v35n03a02

Barbosa-Filho, N. (2018), Composição dos juros líquidos pagos pelo setor público no Brasil: 2002-2017. Revista de Economia Política, 38(3), p. 548-558. doi https://doi.org/10.1590/0101-35172018-2882

Bastos, C., Rodrigues, R., \& Lara, F. M. (2015). As finanças públicas e o impacto fiscal entre 2003 e 2012: 10 anos de governo do Partido dos Trabalhadores. Ensaios FEE, 36(3), p. 675-706.

Belluzzo, L. G., \& Almeida, J. G. (2002). Depois da queda: A economia brasileira da crise da dívida aos impasses do real. Rio de Janeiro: Civilização Brasileira.

Brasil (2016), Emenda Constitucional no 95, de 15 de dezembro de 2016. Altera o Ato das Disposições Constitucionais Transitórias, para instituir o Novo Regime Fiscal, e dá outras providências. Brasília: Casa Civil. Recuperado a partir de http://www.planalto.gov.br/ccivil 03/constituicao/emendas/emc/emc95.htm

Brasil (2021), Nova Previdência. Recuperado a partir de http://www.brasil.gov.br/novaprevidencia/\#novas-regras

Bresser-Pereira, L. C. (2009), A tendência à sobreapreciação da taxa de câmbio. Econômica, 11(1), p. 7-30. doi: https://doi.org/10.22409/economica.11i1.p93

Carcanholo, M. (2010), Inserção externa e vulnerabilidade da economia brasileira no governo Lula. In Magalhaes et al. (Orgs.), Os anos Lula - contribuições para um balanço crítico: 2003-2010 (Cap. 4, pp. 109-132). Rio de Janeiro: Garamond.

Carneiro, R. (2002), Desenvolvimento em crise: A economia brasileira no último quarto do século XX. São Paulo: Unesp. 
Carneiro, R. (2020, 10 setembro), Reservas internacionais e financiamento do investimento. Jornal Le Monde Diplomatique Brasil. Caderno Observatório da Economia Contemporânea, São Paulo. Recuperado a partir de https://diplomatique.org.br/reservas-internacionais-e-financiamentodoinvestimento/

Carneiro, R., \& Mello, G. (2017, 18 março), As reservas internacionais e os mitos da ortodoxia. Jornal GGN o Jornal de Todos os Brasis, São Paulo. Recuperado a partir de https://jornalggn.com.br/noticia/as-reservas-internacionais-e-osmitos-da-ortodoxia-por-ricardo-carneiro-e-guilherme-mello.

Casal Junior, M. (2017, 20 abril), O colchão do crescimento: como as reservas cambiais do Brasil podem ser usadas para sustentar a recuperação da economia. Carta Capital, São Paulo. Recuperado a partir de https:/www.cartacapital.com.br/economia/o-colchao-do-crescimento

Cavalcanti, M., \& Vonbum, C. (2007), Reservas internacionais ótimas para o Brasil: Uma análise simples de custo-benefício para o período 1999-2007. Rio de Janeiro: Instituto de Pesquisa Econômica Aplicada.

Currency Composition of Official Foreign Exchange Reserves. IMF data. Recuperado a partir de http://data.imf.org/?.sk=E6A5F467-C14B-4AA8-9F6D-5A09EC4 $\underline{\mathrm{E} 62 \mathrm{~A} 4}$

Chachamovitz, S. (2016), Reservas internacionais: seguro ou ameaça? In Bacha, E. (Org.), A crise fiscal e monetária brasileira (Cap. 17). Rio de Janeiro: Civilização Brasileira.

Chesnais, F. (1996), A mundialização do capital. São Paulo: Xamã.

De Conti, B., Prates, D., \& Plihon, D. (2014), A hierarquia monetária e suas implicações para as taxas de câmbio e de juros e a política econômica dos países periféricos. 
Economia e Sociedade, 23(2), p. 341-372. doi: https://doi.org/10.1590/S010406182014000200003

Dweck, E., \& Teixeira, R. (2018), Os impactos da regra fiscal em um contexto de desaceleração econômica. In Carneiro, R.; Baltar, P.; Sarti, F. (Orgs.), Para além da política econômica. São Paulo: Editora Unesp Digital.

Ferreira; C. K. L. (2016), A dinâmica da dívida bruta e a relação Tesouro-Banco Central. In Bacha, E. (Org.) A crise fiscal e monetária brasileira (Cap. 12). Rio de Janeiro: Civilização Brasileira.

Fundo Monetário Internacional. World economic outlook database. Recuperado a partir de https://www.imf.org/external/pubs/ft/weo/2016/01/weodata/weoselgr.aspx

Fundo Monetário Internacional (2000), Debt- and reserve- related indicators of external vulnerability. Recuperado a partir de https://www.imf.org/external/np/pdr/debtres/

Fundo Monetário Internacional (2010), reserve accumulation and international monetary Stability. Police Paper, 35, p. 1-35. Recuperado a partir de https://www.elibrary.imf.org/view/journals/007/2010/035/article-A001en.xml. doi: https://doi.org/10.5089/9781498337557.007

Garcia, M. (2018, 30 novembro), Reservas cambiais. Jornal Valor Econômico. Caderno de Opinião, São Paulo. Recuperado a partir de https://valor.globo.com/opiniao/coluna/reservas-cambiais.ghtml

Gentil, D. L., Araujo, V. L. (2012), Dívida pública e passivo externo: onde está a ameaça? Texto para Discussão, Instituto de Pesquisa Econômica e Aplicada, 1768, p. 134. Recuperado a partir de http://repositorio.ipea.gov.br/bitstream/11058/1079/1/TD_1768.pdf 
Gentil, D. L., \& Hermann, J. (2017), A política fiscal do primeiro governo Dilma Rousseff: ortodoxia e retrocesso. Economia e Sociedade, 26(3), p. 793-816. doi: https://doi.org/10.1590/1982-3533.2017v26n3art9

Ghosh, A. R., Ostry, J. D., \& Qureshi, M. S. (2014). Exchange rate management and crisis susceptibility: A Reassessment. International Monetary Fund Work Paper, 14(11), p. 1-46.

Giambiagi, F. (2008), 18 anos de política fiscal no Brasil: 1991/2008. Economia Aplicada, $12(4)$, p. 535-580. doi: https://doi.org/10.1590/\$1413-8050200800 0400002

Gobetti, S. W., \& Schenttini, B. P. (2014), Dívida líquida e dívida bruta: uma abordagem integrada para analisar a trajetória e o custo do endividamento brasileiro. In Santos, C. H.; Gouvêa, R. R. (Orgs.), Finanças públicas e macroeconomia no Brasil: um registro da reflexão do Ipea (2008-2014) (Cap. 13, p. 533-592). Brasília: Ipea.

Goldfajn, I. (2017), Comitê de política cambial para as reservas do Banco Central: uma proposta. Instituto de Estudos de Política, Rio de Janeiro. Recuperado a partir de http://iepecdg.com.br/wpcontent/uploads/2016/04/160419Cap_ Ilan.pdf

Gollo, R., \& Triches, D. (2013), Análise do nível de reservas internacionais dos países emergentes de 2000 a 2010. Revista em Gestão, Educação e Tecnologia Ambiental, 16(16), p. $\quad 3200 \quad-3212 . \quad$ doi: http://dx.doi.org/10.5902/2236117010413

Gottlieb, J. (2018, 16 novembro), A contribution to the debate on international reserves. Macro Vision, Rio de Janeiro. Recuperado a partir de https://www.itau.com.br/_arquivosestaticos/itauBBA/contents/common/docs/ 20181126_MACROVISION_InternationalReserves.pdf 
Heller, R. (1966), Optimal international reserves. The Economic Journal, 76, p. 296-311. doi: http://dx.doi.org/10.2307/2229716

Instituto de Pesquisa Econômica Aplicada (2009), Evolução recente e perspectivas futuras das finanças públicas brasileiras: o comportamento do investimento público em contexto de crise. In Brasil em desenvolvimento: estado, planejamento e políticas públicas. Brasília: Ipea.

Jeanne, O., \& Rancière, R. (2006), The optimal level of international reserves for emerging market countries: Formulas and applications. International Monetary Fund Working Paper, 06(229), p. 1-35.

Jeanne, O., \& Rancière, R. (2011), The optimal Level of International Reserves for Emerging Market Countries: a new formula and some applications. The Economic Journal, 121(555), p.905-930. doi: https://doi.org/10.1111/j.14680297.2011.02435.x

Kaminsky, G.; Reinhart, C. (1999), The twin crises: the causes of banking and balanceof-payments problems. American Economic Review, 89(3), p. 473-500. doi: https://doi.org/10.1257/aer.89.3.473

Laan, C., Cunha, A., \& Lélis, M. (2012), A estratégia de acumulação de reservas no Brasil no período 1995-2008: Uma avaliação crítica. Economia e Sociedade, 1 (21), p. 1-38. doi: https://doi.org/10.1590/S0104-06182012000100001

Macalós, J. P. S. (2020), Accounting for foreign exchange operations and its implications for monetary policy implementation: international experience and the case of Brazil, Brazilian Keynesian Review, 6(1), 100-140. doi: https://doi.org/10.33834/bkr.v6i1.169

Oliveira, C. R. (2019), Retomada do investimento público no Brasil e uso das reservas internacionais: uma contribuição ao debate (Dissertação de Mestrado). 
Universidade Federal Fluminense, Programa de Pós-Graduação em Economia, Niterói/Rio de Janeiro.

Pellegrini, J. (2017), Reservas internacionais: nível adequado, custo fiscal de carregamento e uso no resgate da dívida pública. XXII Prêmio Tesouro Nacional. Recuperado a partir de file:///C:/Users/User/Downloads/1o-lugarjosue-alfredo-pellegrini-021.pdf.

Pellegrini, J. (2019, 39 outubro), Custo de carregamento e nível adequado das reservas internacionais. Instituto Fiscal Independente, Nota Técnica n. 39, Brasília. Recuperado a partir de https://www2.senado.leg.br/bdsf/bitstream/handle/id/563834/NT39_Custo_c arregamento_nivel_reservas_internacionais.pdf.

Pelliser, C., Cunha, A., \& Lélis, M. (2017), Reservas internacionais em tempos de instabilidade financeira: Uma avaliação empírica para o caso do Brasil. Revista Indicadores Econômicos FEE, 44(3), p. 27-46.

Partido dos Trabalhadores. Plano de Governo (2019-2022), Disponível em: https://pt.org.br/wp-content/uploads/2018/08/plano-de-governo_haddad-13 pdf.pdf.

Prates, D. (2002), Crises financeiras nos países emergentes: Uma interpretação heterodoxa. (Tese de Doutorado). Universidade Estadual de Campinas, Programa de Pós-Graduação em Economia, Campinas.

Prates, D. (2015), O regime de câmbio flutuante no Brasil: 1999-2012: especificidades e dilemas. Brasília: Ipea.

Prates, D., Cagnin, R. F., Freitas, M. C. P., \& Novais, L. F. (2014), Balanço do regime de política macroeconômica no primeiro biênio do governo Dilma. In Novais, L. F.; Cagnin, R. F., \& Biasoto Jr., G. (Orgs.), A economia brasileira no contexto da crise global. São Paulo: FUNDAP. 
Ribeiro, F. (2016), Reavaliando a vulnerabilidade externa da economia brasileira. Texto para Discussão, Instituto de Pesquisa Econômica e Aplicada. 2247, p.1-54. Recuperado a partir de http://repositorio.ipea.gov.br/bitstream/11058/7297/1/td_2247.pdf

Rodrik, D. (2006), The social cost of foreign exchange reserves. International Economic Journal, 20(3), p. 253-266. doi: https://doi.org/10.1080/ 10168730600879331

Salomão, J. (2008), Nível ótimo de reservas internacionais para economias emergentes. (Dissertação de Mestrado). Pontifica Universidade Católica do Rio de Janeiro, Programa de Pós-Graduação do Rio de Janeiro, Rio de Janeiro.

Secretaria do Tesouro Nacional (2019), Relatório anual do Tesouro Nacional: Relacionamento entre o Tesouro Nacional e o Banco Central. Brasília: Tesouro Nacional. Recuperado a partir de https://www.tesourotransparente.gov.br/publicacoes/relacionamento-entre-otesouro-nacional-e-obancocentral/2019/30

Serrano, F., \& Pimentel, K. (2017), Será que "acabou o dinheiro"? Financiamento do gasto público e taxas de juros num país de moeda soberana. Revista de Economia Contemporânea, Rio de Janeiro, 2(21), p. 1-29. doi: https://doi.org/10.1590/198055272123

Silva, A. D. B. M., \& Medeiros, O. L. (2009), Conceitos e estatísticas da dívida pública. In Silva, A. C., Carvalho, L. O., \& Medeiros, O. L. (Orgs.). Dívida Pública: a experiência brasileira (Cap. 4, pp. 101-128). Brasília: Banco Mundial.

Vonbum, C. (2013), Reservas internacionais revisitadas: novas estimativas de patamares ótimos. Texto para Discussão, Instituto de Pesquisa Econômica e Aplicada, 1885, p. 1-45. Recuperado a partir de http://repositorio.ipea.gov.br/bitstream/11058/2000/1/TD_1885.pdf. 
Wray, R. (2003), Trabalho e moeda hoje: a chave para o pleno emprego e estabilidade de preços. Rio de Janeiro: Contraponto. 